\title{
Recent Development and Challenges in Spectroscopy and Machine Vision Technologies for Crop Nitrogen Diagnosis: A Review
}

\author{
Daoliang Li ${ }^{1,2,3,4,5, *}$, Pan Zhang ${ }^{1,2,3,4,5}$, Tao Chen ${ }^{6}\left(\mathbb{C}\right.$ and Wei Qin ${ }^{7}(\mathbb{C}$ \\ 1 National Innovation Center for Digital Fishery, China Agricultural University, P.O. Box 121, 17 Tsinghua East \\ Road, Beijing 100083, China; zp_cau@163.com \\ 2 Beijing Engineering and Technology Research Centre for Internet of Things in Agriculture China Agriculture \\ University, Beijing 100083, China \\ 3 China-EU Center for Information and Communication Technologies in Agriculture, China Agriculture \\ University, Beijing 100083, China \\ 4 Key Laboratory of Agricultural Information Acquisition Technology, Ministry of Agriculture, \\ China Agriculture University, Beijing 100083, China \\ 5 College of Information and Electrical Engineering, China Agricultural University, Beijing 100083, China \\ 6 Department of Chemical and Process Engineering, University of Surrey, Guildford GU2 7XH, UK; \\ t.chen@surrey.ac.uk \\ 7 College of Resources and Environmental Sciences; National Academy of Agricultural Green Development; \\ Key Laboratory of Plant-Soil Interactions, Ministry of Education, China Agricultural University, \\ Beijing 100193, China; wei.qin@cau.edu.cn \\ * Correspondence: dliangl@cau.edu.cn; Tel.: +86-10-6273-7679; Fax: +86-10-6273-7741
}

Received: 30 June 2020; Accepted: 5 August 2020; Published: 11 August 2020

\begin{abstract}
Recent development of non-destructive optical techniques, such as spectroscopy and machine vision technologies, have laid a good foundation for real-time monitoring and precise management of crop $\mathrm{N}$ status. However, their advantages and disadvantages have not been systematically summarized and evaluated. Here, we reviewed the state-of-the-art of non-destructive optical methods for monitoring the $\mathrm{N}$ status of crops, and summarized their advantages and disadvantages. We mainly focused on the contribution of spectral and machine vision technology to the accurate diagnosis of crop $\mathrm{N}$ status from three aspects: system selection, data processing, and estimation methods. Finally, we discussed the opportunities and challenges of the application of these technologies, followed by recommendations for future work to address the challenges.
\end{abstract}

Keywords: crops; nitrogen status; diagnosis; spectroscopy; vision

\section{Introduction}

Nitrogen $(\mathrm{N})$ plays a key role in the growth of agricultural crops. $\mathrm{N}$ is the main component of protein that must be involved in the growth and division of cells and the formation of new cells in the process of crop growth and development. $\mathrm{N}$ is the component of nucleic acid and nuclear protein, and nucleic acid is the basic material for plant growth, development and life activities. $\mathrm{N}$ is a component element of many enzymes that are biocatalysts in biochemical and metabolic processes in plants. The direction and speed of many biochemical reactions in plants are controlled by enzyme systems. $\mathrm{N}$ is also a component element of chlorophyll, the content of chlorophyll often directly affects the rate of photosynthesis and the formation of photosynthetic products. It not only determines the photosynthesis of crops but also further determines the yield and quality of crops. Therefore, $\mathrm{N}$ availability is a key limiting factor for crop growth and productivity [1,2]. N deficiency can lead to the reduction of leaf 
size and chlorophyll content, which directly affect crop yield and quality [3,4]. Conversely, excessive $\mathrm{N}$ application may lead to serious environmental pollution [5]. $\mathrm{N}$ loss due to fertilization is a major non-point pollution source for the atmosphere and water bodies, and groundwater pollution due to nitrate- $\mathrm{N}\left(\mathrm{NO}_{3}-\mathrm{N}\right)$ has become an urgent problem in most countries [6,7]. Meanwhile, nitrous oxide $\left(\mathrm{N}_{2} \mathrm{O}\right)$ is an important and powerful greenhouse gas with 265 times han $\mathrm{CO}_{2}$ [8]. Therefore, efficient and precise tools for diagnosis of $\mathrm{N}$ status is key to improving crop productivity and reducing environmental pollution.

Many crop $\mathrm{N}$ diagnosis methods have been developed (Table 1), which can be categorized as traditional methods (destructive diagnosis) and non-destructive methods (reflectance-based, transmittance-based, and machine vision methods) [9]. Among them, traditional methods such as Kjeldahl-digestion (shown in Figure 1) need to collect a large number of samples in advance and carry out pre-processing, wet digestion, distillation, ammonium estimation steps to determine the $\mathrm{N}$ status of crops [10]. However, these methods are time-consuming and have high cost, thereby limiting their use [11,12]. There are many other examples such as leaf color chart and soil and plant analyzer development (SPAD) proposed for rapid and non-destructive estimation of crop $\mathrm{N}$ status in situ [13,14]. However, these methods mainly focus on the individual leaves [15]. Hence, developing real-time and non-destructive methods for crop $\mathrm{N}$ status diagnosis at large scales is particularly important.

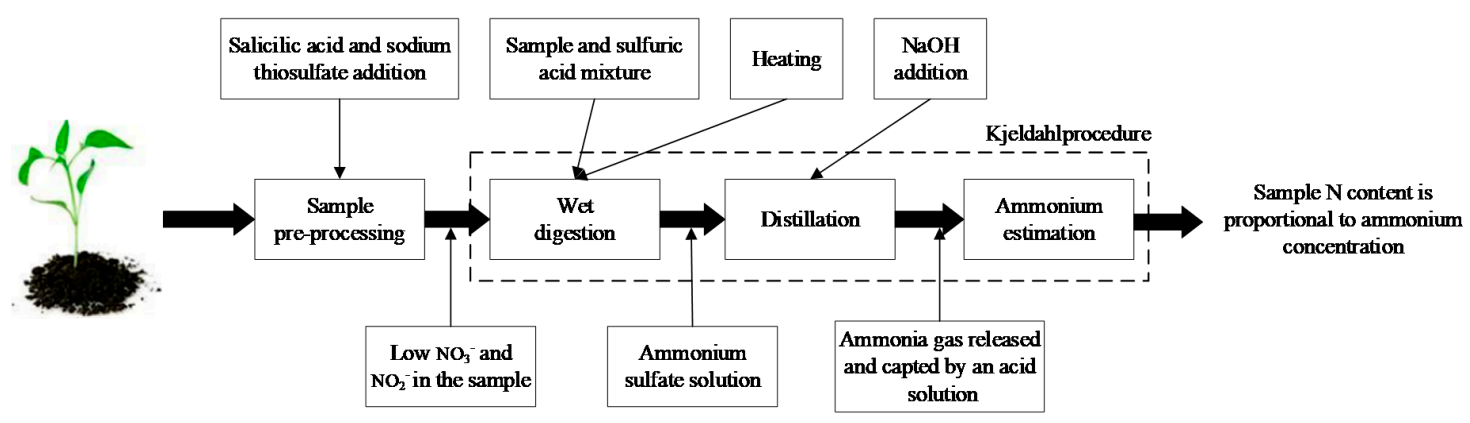

Figure 1. Kjeldahl wet digestion procedure.

Remote sensing has the advantages of non-destructive and rapid acquisition of crop growth information at large scale $[16,17]$. For example, near-ground remote sensing can provide real-time and relatively low-cost information about crop $\mathrm{N}$ status [18]. As we can see from Table 1, the reflective sensor mainly estimates the $\mathrm{N}$ status based on the spectral information of crop canopy, while the transmission sensor mainly estimates the $\mathrm{N}$ status based on the spectral information of crop leaves. The two kinds of sensors aim at different levels of measurement objects. Among them, the active sensor has its own light source and does not depend on natural light or external environment; while the passive sensor relies on natural light and is greatly affected by the external environment. Some instruments such as Yara N-sensors, GreenSeeker reflectance meters, hyperspectral reflectance meters, and the LAI-2000 canopy analyzer (LI-COR Inc., USA) have been used for detecting crop growth and nutrient status by near-ground remote sensing [19-22]. Machine vision technologies are also widely used in crop N status diagnosis [23,24].

Previous reviews on $\mathrm{N}$ status diagnosis mostly focus on a few specific aspects, such as specific species [25], diagnostic equipment [26-28], or machine learning methods [29]. As yet, there is no comprehensive review on the application of spectroscopy and machine vision technology in $\mathrm{N}$ status diagnosis. Hence, the objectives of this review are (1) to evaluate the state-of-the-art of non-destructive optical methods for monitoring the $\mathrm{N}$ status of crops, and to summarize their advantages and disadvantages; (2) to discuss their application from three aspects: system selection, data processing, and estimation methods; (3) to discuss the opportunities and challenges of the application of these methods. 
Table 1. A summary of the methods for diagnosis of $\mathrm{N}$ status.

\begin{tabular}{|c|c|c|c|c|c|c|c|}
\hline Sensor Type & Device & $\begin{array}{l}\text { Measuring } \\
\text { Principle }\end{array}$ & Wavelengths Used & Scale & Advantage & Disadvantage & Reference \\
\hline \multirow{3}{*}{$\begin{array}{l}\text { Traditional } \\
\text { methods }\end{array}$} & Kjeldahl digestion & Tissue analysis & - & $\begin{array}{l}\text { Leaf or whole } \\
\text { plant }\end{array}$ & $\begin{array}{l}\text { Can estimate total } \mathrm{N} \text { contents } \\
\text { (protein, acids, amino, nucleic } \\
\text { acids) }\end{array}$ & $\begin{array}{c}\text { Destructive and invasive } \\
\text { Time-consuming } \\
\text { Sample preprocessing } \\
\text { requirements } \\
\text { Toxic reagents used }\end{array}$ & [10] \\
\hline & Leaf color chart & Visual comparison & - & Leaf & $\begin{array}{c}\text { Low cost } \\
\text { Minimum training } \\
\text { Quick } \\
\text { Non-destructive } \\
\text { Portable } \\
\end{array}$ & Not accurate & [13] \\
\hline & Dumas combustion & Tissue analysis & - & $\begin{array}{l}\text { Leaf or whole } \\
\text { plant }\end{array}$ & No nitrite and nitrate reduction & $\begin{array}{c}\text { Destructive } \\
\text { Sample preprocessing } \\
\text { requirements } \\
\mathrm{N} \text { loss because of } \\
\text { incomplete combustion }\end{array}$ & [16] \\
\hline \multirow{11}{*}{ Reflectance sensor } & $\begin{array}{c}\text { Yara } \\
\text { N-sensor/Fieldscan }\end{array}$ & Reflectance (passive) & $450-900$ & Canopy & $\begin{array}{l}\text { Quick } \\
\text { Accurate } \\
\text { Portable }\end{array}$ & $\begin{array}{l}\text { Not suitable for paddy } \\
\text { fields } \\
\text { Required training }\end{array}$ & [19] \\
\hline & GreenSeeker & Reflectance (active) & 650,770 & Canopy & \multirow{2}{*}{$\begin{array}{c}\text { With light sources } \\
\text { Non-destructive } \\
\text { Quick } \\
\text { Simple } \\
\text { Portable }\end{array}$} & \multirow{2}{*}{$\begin{array}{l}\text { Low correlation of } \\
\text { determination } \\
\text { Not accurate } \\
\text { Noises in background }\end{array}$} & [20] \\
\hline & $\begin{array}{l}\text { GreenSeeker } \\
\text { Handheld }\end{array}$ & Reflectance (active) & 660,780 & Canopy & & & [20] \\
\hline & MSR5/87/16R & Reflectance (passive) & $\begin{array}{l}460,510,560,610 \\
660,710,760,810\end{array}$ & Canopy & \multirow[t]{2}{*}{ Can detect a wide range field area } & \multirow[t]{2}{*}{$\begin{array}{l}\text { Calibration is required } \\
\text { Sunlight dependence }\end{array}$} & [25] \\
\hline & CropSpec & Reflectance (passive) & $730-740,800-810$ & Canopy & & & [25] \\
\hline & Fritzmeier ISARIA & Reflectance (passive) & - & Canopy & $\begin{array}{l}\text { Easy to operate and can be } \\
\text { carried on mobile vehicles }\end{array}$ & Sunlight dependence & [26] \\
\hline & OptRx Crop Sensor & Reflectance (active) & $670,728,775$ & Canopy & \multirow{5}{*}{$\begin{array}{c}\text { With light sources } \\
\text { Non-destructive } \\
\text { Quick } \\
\text { Simple } \\
\text { Portable }\end{array}$} & \multirow{5}{*}{$\begin{array}{l}\text { Low correlation of } \\
\text { determination } \\
\text { Not accurate } \\
\text { Noises in background }\end{array}$} & [27] \\
\hline & N-sensor ALS & Reflectance (active) & $670,730,760$ & Canopy & & & [27] \\
\hline & Crop Circle ACS 430 & Reflectance (active) & $670,730,780$ & Canopy & & & [27] \\
\hline & Crop Circle ACS 470 & Reflectance (active) & $\begin{array}{l}450,550,650,670 \\
730,760\end{array}$ & Canopy & & & [27] \\
\hline & RapidScan CS-45 & Reflectance (active) & $670,730,780$ & Canopy & & & [27] \\
\hline
\end{tabular}


Table 1. Cont.

\begin{tabular}{|c|c|c|c|c|c|c|c|}
\hline Sensor Type & Device & $\begin{array}{l}\text { Measuring } \\
\text { Principle }\end{array}$ & Wavelengths Used & Scale & Advantage & Disadvantage & Reference \\
\hline \multirow{6}{*}{$\begin{array}{l}\text { Transmittance } \\
\text { sensor }\end{array}$} & DUALEX & Transmittance & 710,850 & Leaf & \multirow{6}{*}{$\begin{array}{c}\text { Simple } \\
\text { Non-destructive } \\
\text { Quick } \\
\text { Portable }\end{array}$} & \multirow{6}{*}{ Needs field references } & [27] \\
\hline & SPAD-502 & Transmittance & 650,940 & Leaf & & & [28] \\
\hline & N-tester & Transmittance & 650,960 & Leaf & & & {$[30]$} \\
\hline & atLEAF+ & Transmittance & 660,940 & Leaf & & & [31] \\
\hline & $\begin{array}{l}\text { MC-100 Chlorophyll } \\
\text { Concentration Meter }\end{array}$ & Transmittance & 653,931 & Leaf & & & [32] \\
\hline & $\begin{array}{l}\text { CCM-200 Chlorophyll } \\
\text { Content Meter Plus }\end{array}$ & Transmittance & 653,931 & Leaf & & & [33] \\
\hline \multirow[b]{2}{*}{$\begin{array}{l}\text { Machine vision } \\
\text { sensor }\end{array}$} & Digital cameras & Vision & - & - & $\begin{array}{l}\text { No complicated instruments and } \\
\text { experimental steps are required }\end{array}$ & Sunlight dependence & [34] \\
\hline & Yara ImageIT & Vision & - & - & $\begin{array}{c}\text { Simple } \\
\text { Non-destructive } \\
\text { Quick } \\
\text { Portable }\end{array}$ & Sunlight dependence & [35] \\
\hline
\end{tabular}




\section{Real-Time Non-Destructive Diagnostic Methods}

Spectral and machine vision technology have become the main choices for crop N status diagnosis. As an optical sensor, it enables rapid and periodic assessment of crop $\mathrm{N}$ status [36]. As shown in Figure 2, for the spectral technology, we can use it to obtain the spectral information of crop leaves and canopy, respectively, and then use the data pre-processing method to obtain the characteristic bands. For machine vision technology, we can use it to obtain the image information of crop leaves and canopy, and then obtain the feature information through image segmentation and feature extraction. Among them, the spectral information or image information of canopy can not only reflect the $\mathrm{N}$ status of crop canopy, but also reflect the $\mathrm{N}$ status of the whole plant. Then the destructive methods (such as the Kjeldahl method) are used to obtain the actual $\mathrm{N}$ status of the crop. Based on the correlation analysis between spectral feature band or image feature information and crop actual $\mathrm{N}$ status, the estimation model of crop leaf, canopy, and whole plant N status are established. However, the quality of the $\mathrm{N}$ status estimation model is often affected by the external environment factors, such as external light, soil background, etc.

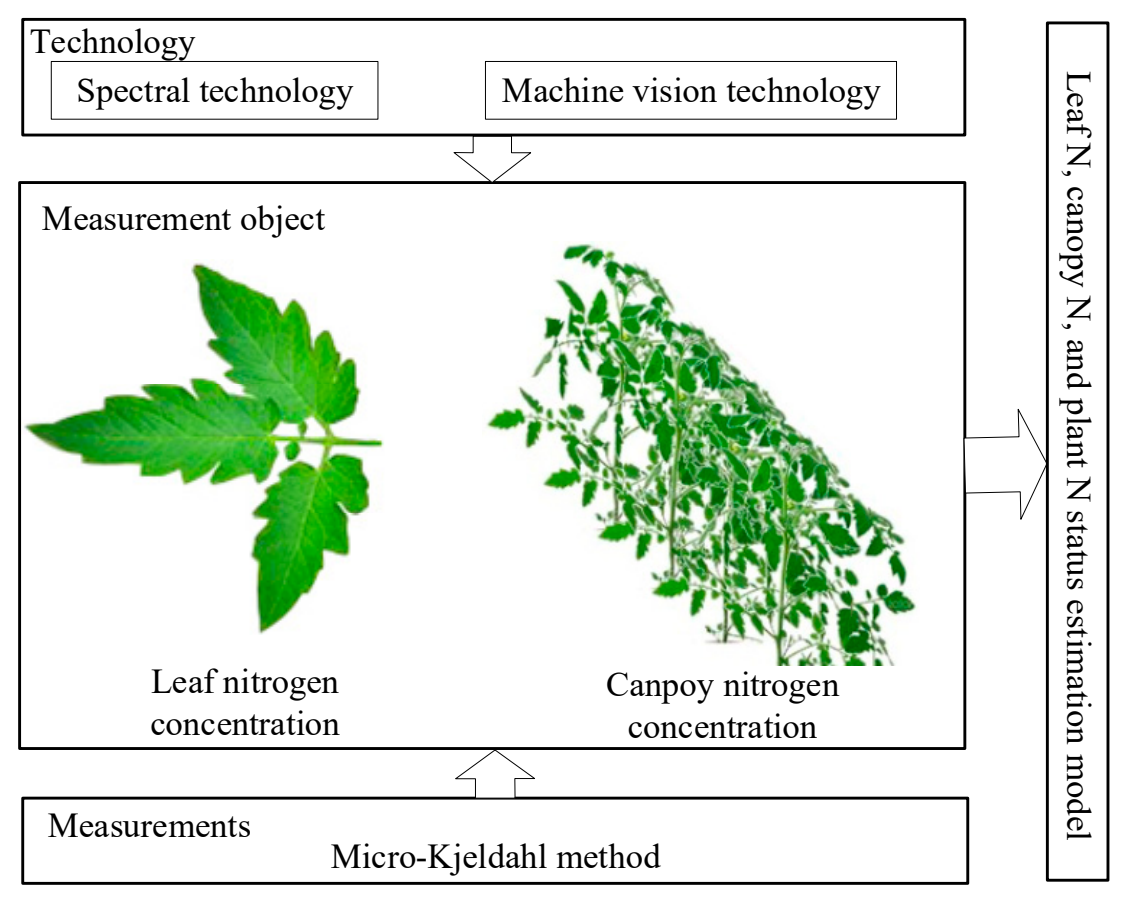

Figure 2. Basic principles of N non-destructive diagnosis.

\subsection{Spectral Technology}

Spectral reflectance is a promising and convenient index for continuous sampling and narrow wave selection, which can sensitively reflect the specific physiological variables of crops $[37,38]$. Within the range of 350-1300 nm, the accurate measurement of leaf spectral reflectance depends on the interaction between light and crops and its influence on the spectral characteristics of green leaves, which enable accurate quantification of the crop $\mathrm{N}$ status [39]. Among them, we usually use hand-held or near ground spectral sensors to collect the crop leaf spectral information and unmanned aerial vehicle (UAV) or remote sensing technology to collect the spectral information of large-scale crops canopy in the visible and near-infrared spectral band range (Figure 3). Then, the data pre-processing method is used to select the characteristic band, and the appropriate estimation method is selected to construct the $\mathrm{N}$ status estimation model. 


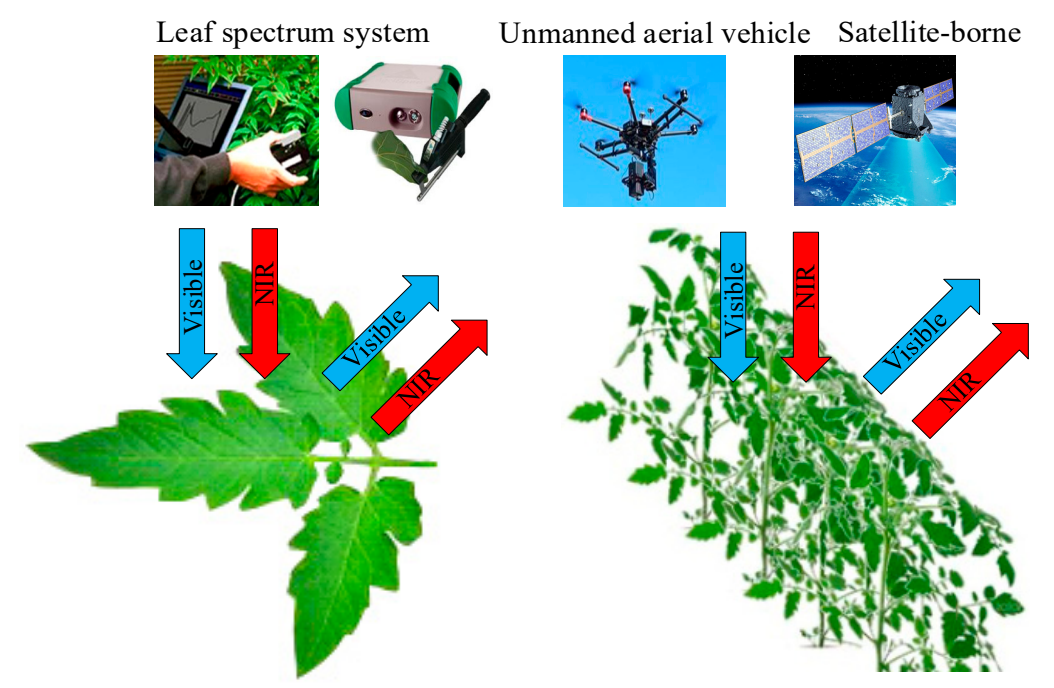

Figure 3. Basic principles of spectral technology.

\subsubsection{Application of Spectral System Selection to the Diagnosis of Crop N Status}

Recently, a number of remote sensing systems have been proposed for the assessment of crop N status, such as the compact airborne spectrographic imager system [6], the hyperspectral LiDAR(HSL) [39-41], remote sensing with hyperspectral system [42], the QuickBird satellite with multi-spectral system [43], and others [44-46]. Hyperspectral sensors describe the reflectance of crop canopy in more information than multispectral sensors [47], which mainly includes two forms: non-imaging and imaging [48,49]. The non-imaging measurement can only obtain a small amount of spectral information of sampling points, and it cannot achieve the rapid and efficient information acquisition of large-area crops [49]. The imaging measurement such as satellite-borne hyperspectral imaging technology can obtain a wide range of spectral information, but also has some problems, such as long revisit period, limited breadth, low spatial resolution (generally less than $30 \mathrm{~m}$ ), etc. [50]. Airborne hyperspectral imaging technology has the characteristics of mobility and flexibility. However, it is subject to air traffic control and requires high light conditions [51]. Consequently, the data collection cost based on this method is high, and its popularization and application in precision agriculture are limited. Compared with the aforementioned satellite-borne hyperspectral imaging technology and airborne hyperspectral imaging technology, UAV-based remote sensing measurement technology has the characteristics of low flight control, efficient use, flexible, and low operating cost [52], which can offer particular advantages with a high spatial resolution, an appropriate revisit time, and a spectral resolution adjusted for a specific task $[47,53,54]$. Besides, the combination of other methods and spectral technology such as the combination of spectroscopy and SPAD [55], the combination of Ground-Based Hyperspectral and UAV-Based Multispectral Imagery for crop N status assessment in rice [47], and the combination of physical optics approach and UAV-based hyperspectral imagery has great potential for assessing canopy $\mathrm{N}$ density (CND) in winter wheat [56].

\subsubsection{Application of Spectral Data Processing to the Diagnosis of Crop N Status}

The data obtained by spectral technology have collinearity, high redundancy, sometimes noise and spectral autocorrelation [47], the estimation ability, and calculation efficiency of the model can be reduced [57]. Thus, the commonly used spectral preprocessing methods are multiplicative scatter correction (MSC), Savitzky-Golay smoothing (SGS), first-derivative (1-Der), second-derivative (2-Der), standard normal variable (SNV), etc. [48]. Besides, there are other methods to extract the spectral information of the target, including continuum removal methods, hyperspectral vegetation indices, multivariable statistical methods, and differential technique [58,59]. Therefore, it is of great significance to select the most critical spectral bands for crop $\mathrm{N}$ status estimation. At present, there are many 
spectral indices or vegetation indices for diagnosis of crop $\mathrm{N}$ status [60,61]. Therefore, we selected core and novel indexes to summarize. A summary of spectral or vegetation indices commonly used for diagnosing crop $\mathrm{N}$ status is shown in Table 2.

Table 2. Summary of the selected existing vegetation indices (VIs) or spectral indices that are sensitive to the $\mathrm{N}$ status.

\begin{tabular}{|c|c|c|c|}
\hline Vegetation/Spectral Indices & Abbreviation & Formula & Reference \\
\hline Ratio spectral index & RSI & $\operatorname{RSI}\left(D_{11}, D_{12}\right)=D_{11} / D_{12}$ & [62] \\
\hline Soil adjusted vegetation index & SAVI & $\begin{array}{c}\operatorname{SAVI}\left(\mathrm{R}_{11}, \mathrm{R}_{12}\right)= \\
\left(\mathrm{R}_{11}-\mathrm{R}_{12}\right)\left(\mathrm{R}_{11}+\mathrm{R}_{12}+\mathrm{L}\right)(1+\mathrm{L})\end{array}$ & [62] \\
\hline Normalized ratio index & NRI & $\mathrm{NRI}_{1510}=\left(\mathrm{R}_{1510}-\mathrm{R}_{660}\right) /\left(\mathrm{R}_{1510}+\mathrm{R}\right)$ & [62] \\
\hline Double-peak canopy N index & DCNI & $\left(\mathrm{R}_{11}-\mathrm{R}_{12}\right)\left(\mathrm{R}_{12}-\mathrm{R}_{13}\right) /\left(\mathrm{R}_{11}-\mathrm{R}_{13}+0.03\right)$ & [63] \\
\hline Normalized Area Over reflectance curve & NAOC & $1-\left(\int_{643}^{773} \mathrm{Rdr}\right)\left(30 \times \mathrm{R}_{\max }\right)$ & [64] \\
\hline Blue nitrogen index & BNI & $\mathrm{R}_{434} /\left(\mathrm{R}_{496}+\mathrm{R}_{401}\right)$ & [65] \\
\hline Red edge Reflectance curve area & REFCA & $\operatorname{SUM}\left(\mathrm{R}_{\mathrm{i}} / \mathrm{R}_{780}\right), \mathrm{i}=680-780$ & [66] \\
\hline Normalized difference spectral index & NDSI & $\begin{array}{c}\operatorname{NDSI}\left(\mathrm{R}_{11}, \mathrm{R}_{12}\right)= \\
\left(\mathrm{R}_{11}-\mathrm{R}_{12}\right) /\left(\mathrm{R}_{11}+\mathrm{R}_{12}\right)\end{array}$ & [67] \\
\hline First derivative & - & $\mathrm{D}_{736}=\left(\mathrm{R}_{736}-\mathrm{R}_{735}\right) / 1 \mathrm{~nm}$ & [68] \\
\hline Combined index & - & $\mathrm{D}_{736} \times \mathrm{R}_{990} / \mathrm{R}_{720}$ & [68] \\
\hline Broadband $\mathrm{CI}_{\text {red-edge }}$ & $\mathrm{CI}_{\text {red-edge }}$ & $\mathrm{R}_{783} / \mathrm{R}_{705}-1$ & [69] \\
\hline Broadband CI green & $\mathrm{CI}_{\text {green }}$ & $\mathrm{R}_{783} / \mathrm{R}_{560}-1$ & [69] \\
\hline Difference index of the double-peak areas & DIDA & $\left(\mathrm{R}_{11}+\mathrm{R}_{12}-2 \times \mathrm{R}_{13}\right) /\left(\mathrm{R}_{11}-\mathrm{R}_{12}\right)$ & [70] \\
\hline \multirow{2}{*}{ Multi-angular vegetation index } & $\mathrm{MAVI}_{\mathrm{SR}}$ & $\left(\mathrm{R}_{11} / \mathrm{R}_{12}\right) \mathrm{Z} 1-\left(\mathrm{R}_{13} / \mathrm{R}_{14}\right) \mathrm{Z} 2$ & [71] \\
\hline & $\mathrm{MAVI}_{\mathrm{ND}}$ & $\begin{array}{c}\left(\left(\mathrm{R}_{11}-\mathrm{R}_{12}\right) /\left(\mathrm{R}_{11}+\mathrm{R}_{12}\right)\right) \mathrm{Z1}-\left(\left(\mathrm{R}_{13}-\right.\right. \\
\left.\left.\mathrm{R}_{14}\right) /\left(\mathrm{R}_{13}+\mathrm{R}_{14}\right)\right) \mathrm{Z2}\end{array}$ & [71] \\
\hline Red-edge absorption valley area & REA & $1 / 2 \times\left(R_{1}+D_{1}-R_{1}\right) \times D 1$ & [72] \\
\hline Normalized vegetation index & NDVI & $\left(\mathrm{R}_{800}-\mathrm{R}_{680}\right) /\left(\mathrm{R}_{800}+\mathrm{R}_{680}\right)$ & [73] \\
\hline Normalized difference705 & ND705 & $\left(R_{750}-R_{705}\right) /\left(R_{750}+R_{705}\right)$ & [74] \\
\hline Green normalized vegetation index & GNDVI & $\left(R_{801}-R_{550}\right) /\left(R_{801}+R_{550}\right)$ & [75] \\
\hline $\begin{array}{l}\text { The modified chlorophyll absorption } \\
\text { ratio index }\end{array}$ & MCARI & $\begin{array}{c}{\left[\left(R_{700}-R_{670}\right)-0.2\left(R_{700}-\right.\right.} \\
\left.\left.R_{550}\right)\right]\left(R_{700} / R_{670}\right)\end{array}$ & [75] \\
\hline Transformed carotene like index & TCARI & $\begin{array}{c}3\left[\left(\mathrm{R}_{700}-\mathrm{R}_{670}\right)-0.2\left(\mathrm{R}_{700}-\right.\right. \\
\left.\left.\mathrm{R}_{550}\right)\left(\mathrm{R}_{700} / \mathrm{R}_{670}\right)\right]\end{array}$ & [76] \\
\hline Optimizing soil adjusted vegetation index & OSAVI & $\begin{array}{c}(1+0.16)\left(\mathrm{R}_{800}-\right. \\
\left.\mathrm{R}_{670}\right) /\left(\mathrm{R}_{800}+\mathrm{R}_{670}+0.16\right)\end{array}$ & [77] \\
\hline
\end{tabular}

$R_{\lambda}$, the reflectance at $\lambda \mathrm{nm} ; D_{\lambda}$ the first derivative of reflectance spectral at $\lambda \mathrm{nm}$.

The diagnosis of crop $\mathrm{N}$ status at leaf scales is the basis of crop population $\mathrm{N}$ status diagnosis. Some studies reported that there is a good correlation between crop $\mathrm{N}$ status and leaf spectral data [62-67], and different spectral indices are suitable for different crops and their growing stages [68,69]. Several spectral indices (SIs) such as the ratio index (RI), normalized difference spectral index (NDSI) [70-76], and others [78-83] are used for leaf N content (LNC) estimation based on leaf reflectance. However, most of these indices focus on two or three bands only. Because different crops have different sensitive bands in different growth stages of $\mathrm{N}$ diagnosis, which has certain limitations in the realization of comprehensive and accurate diagnosis of crop N status. Therefore, it is difficult to establish a unified index to evaluate LNC in the different growth periods, varieties, and sites. However, the optimum multiple narrow band reflectance (OMNBR) models was proposed by [60] significantly increase the accuracy for estimating the LNC $\left(R^{2}=0.670 .71\right)$ and plant $N$ concentration $(P N C)\left(R^{2}=0.570 .78\right)$ with six bands. Except for that mentioned above, some NDVI-like indices derived from different diagnostic wavelengths have been proposed for monitoring $\mathrm{N}$ status [84-88]. However, due to the interference of soil background, NDVI values will change and reach saturation at moderate-to-high vegetation densities. Some indices such as the leaf N content spectral indices (LNCSI) [89], which has a good effect on the quantitative inversion of LNC in wheat leaves. However, the latter only evaluated the $\mathrm{N}$ content of wheat leaves at flag leaf stage and flowering stage, but did not consider other growth stages. The $\mathrm{CI}_{\text {red-edge }}$ [90] can provide a more accurate and stable estimation of the LNC in maize, which can accurately reflect to the dynamic changes of leaf $\mathrm{N}$ status during different growth stages of maize. Besides, for the diagnosis of leaf $\mathrm{N}$ status in different varieties, sites, and phenological 
characteristics, a new index named dual peak area normalized difference (NDDA) was proposed by Feng et al. [64], which has the advantages of good stability and strong monitoring ability for this problem. Therefore, there are many challenges and problems in the diagnosis of leaf $\mathrm{N}$ status on different crops and growth stages.

The diagnosis of crop $\mathrm{N}$ status at canopy level is an effective method for accurate diagnosis of crop population $\mathrm{N}$ status. The spectral characteristics of the canopy can represent the growth information of vegetation canopy $[15,91]$. However, leaf reflectance is relatively high in the near-infrared regions due to the multi scattering and low chlorophyll absorption and relatively low in the visible wavelengths due to the high chlorophyll absorption [92] Monitoring leaf nitrogen status with hyperspectral reflectance in wheat]. To address this issue, some chlorophyll red-edge and plant $\mathrm{N}$ spectral indices, such as $\mathrm{SD}_{\mathrm{r}} / \mathrm{SD}_{\mathrm{b}}, \mathrm{DIDA}$, and $\mathrm{RSI}\left(\mathrm{D}_{740}, \mathrm{D}_{522}\right)$ for assessing canopy $\mathrm{N}$ status have been developed $[50,93,94]$. Besides, canopy chlorophyll content index (CCCI) based on the normalized difference red edge (NDRE) and NDVI was developed [95]. When the canopy cover is above $30 \%$, as an effective indicator, NDRE can be used to estimate crop N status. However, due to the influence of leaf characteristics, canopy structure, atmospheric conditions, and soil background, the obtained canopy spectra are mixed spectral information $[23,86]$.

First, the vegetation index is effective in reducing the influence of different backgrounds and can improve the reflectance sensitivity to crop N status. For example, the SAVI can minimize the soil background interference through a soil regulating parameter $\mathrm{L}$, which is widely used in the measured and simulated data. Meanwhile, it has been proved that it can effectively decrease the impact of soil background and correct normalized difference spectral index (NDSI) for better diagnostic performance [96]. However, SAVI must know the density distribution or coverage percentage of the underlying vegetation in advance, so it is only suitable for extracting the vegetation information of the underlying vegetation in a small area with small vegetation coverage change. Besides, a multi-angular vegetation index $\left(\mathrm{MAVI}_{\mathrm{SR}}\right)$, two red-edge-based indices, and red edge chlorophyll index $\left(\mathrm{CI}_{\mathrm{RE}}\right)$ have also proved to have a good performance in crop canopy $\mathrm{N}$ status diagnostics [71,97].

Second, regarding water absorption of fresh leaves, a water removal technology was proposed [98], whose main idea is to remove the influence of water absorption and improve the diagnosis of $\mathrm{N}$ status [99,100] and N-P ratio [101]. By water removal technology and combining continuous wavelet analysis (CWA) in the SWIR, a better effect can be achieved. Additionally, the Datt index, Medium Resolution Imaging Spectrometer (MERIS) terrestrial chlorophyll indices (MTCI), a water resistance N index (WRNI) was also proposed to increase the accuracy of the LNC estimation model by minimizing the influence of water stress [102].

Third, regarding the influence of canopy structure change, using ratio vegetation index (RVI) can slow down the expansion of saturation under dense canopies, which is still sensitive to the change of vegetation state after canopy closure [103]. However, the vegetation coverage affects RVI. When the vegetation coverage is high, RVI is very sensitive to vegetation. When the vegetation coverage is less than $50 \%$, the sensitivity decreases significantly. Therefore, Li et al. [104] conducted a study on rice of different years, varieties, and growth stages, and found that RVI could be used to estimate the $\mathrm{N}$ status of over fertilized winter wheat before heading. Meanwhile, the RVI is affected by atmospheric conditions, which greatly reduces the sensitivity of vegetation detection, so atmospheric correction or reflectance calculation of RVI is needed before calculation.

Finally, the relationship between the index and $\mathrm{N}$ status is often inconsistent, due to the change of canopy background and growth status in different stages of crop. GNDVI has been proposed as the most suitable spectral index to estimate the leaf $\mathrm{N}$ content in each growth stage of the corn, while SAVI performs better at the beginning of the season [105]. However, the canopy structure of different crops is different. Therefore, a different vegetation index or spectral index should be proposed for different crops in the later research to estimate the $\mathrm{N}$ status of crops.

Whether it is leaf or canopy scale, the increase of computation and the massive data characteristics easily cause complex problems such as overfitting, which affects the estimation of the model. There are 
some methods to obtain the most relevant sensitive bands from high-dimensional data samples. For instance, the combination of principal component analysis (PCA) with a genetic algorithm [106], the partial least squares regression (PLSR) [107], and the Gaussian process regression (GPR) [108] can reduce the dimensionality of the original data, thereby decreasing redundant information in the data and obviously increasing the data validity.

\subsubsection{Application of Estimation Methods Based on Spectral Data to Crop N Status Diagnosis}

Although the accuracy of classification or regression can be significantly enhanced by increasing the number of wavelengths in the calculation process [40], the correct use of estimation methods is very important to improve the accuracy of crop $\mathrm{N}$ status diagnosis. Most studies used linear or multiple nonlinear regression models to construct the relationship between the spectral index and $\mathrm{N}$ status [109,110]. However, when the data contains a large number of characteristic dimensions, the correlation between these spectral indices and leaf $\mathrm{N}$ status are usually not very high, the estimation model is prone to overfitting and losing the accuracy of estimation. To solve the problems of multicollinearity and overfitting [45], the PLSR method can decrease extensive collinear variables to a little non-correlated factor and reduce the influence of background effects on model accuracy [111-113]. Meanwhile, PLSR usually stresses contiguous data, full-spectrum and efforts to identify and subset related spectral features are always ignored. The genetic algorithm with PLSR can realize the latter goals, but studies using this method are far fewer than that using PLSR alone [114]. Furthermore, based on the SAIL canopy model and the N-based PROSPECT model, an N-PROSAIL model was established and used for estimating crop $\mathrm{N}$ content both at canopy and leaf scales and which was proved to have great potential for crop $\mathrm{N}$ status diagnosis in wheat [115].

Machine learning in crop N status diagnosis was reported in many recent studies $[12,49,116,117]$. For example, the artificial neural network (ANN) [12], the error backpropagation artificial neural network (BP-ANN) [45], the support vector machine (SVM) [118,119], SVM-PLS [120], and wavelet transform [121]. After comparing the stepwise multiple linear regression (SMLR) and ANN models of mangroves, it was found that the use of the ANN method for $\mathrm{N}$ status estimation produces satisfactory results [12]. ANNs also has many advantages in nonlinear modeling, because of its robustness and estimation ability under incomplete or noisy data [122]. However, there are some drawbacks such as complex input-response relationships in the use of ANNs for nonlinear modeling, which may not conform to physical or biological models [34]. The support vector regression (SVR) based radial basis function (RBF) kernel is better than the SMLR in canopy N content (CNC) estimation [117]. However, compared with general regression neural networks, SVR, and band ratio polynomial regression, the GPR has higher estimation accuracy [123]. As discussed by Verrelst et al. [124], GPR is more flexible for choosing kernel type than SVM and easier to train than the neural network [125]. Furthermore, some studies have demonstrated that the combination of other methods based on SVM has a higher advantage in the assessment of $\mathrm{N}$ status, such as least squares support vector machines (LS-SVM) and Savitzky-Golay support vector machines (SG-SVM) [48]. With the development of deep learning, it has been widely used in the field of agricultural research. However, there are few applications in spectral data processing and estimation. Deep learning can automatically combine and transform the low-order features of input data to get high-order features, which saves the manual work of constructing high-order features. Therefore, the feature extraction process based on deep learning is more accurate and faster, and we can use deep learning to extract features and establish models in order to achieve a better model estimation effect.

In summary, although there are many measurement systems, data processing methods, and modeling algorithms mentioned above in the field of crop $\mathrm{N}$ status diagnosis, there are huge differences in the selection of spectral system, data pre-processing methods, and estimation methods due to the complex and variable crop growth environment and the influence of many factors. Therefore, it is difficult to find a unified measurement system, data processing method, and modeling 
algorithm to deal with the non-destructive diagnosis task of different agricultural scenes for the study of crop $\mathrm{N}$ status. Therefore, the future research should be devoted to make up for this problem.

\subsection{Machine Vision Technology}

The machine vision technology can visually evaluate the $\mathrm{N}$ status by the shape, color, and texture of crops, and determine the $\mathrm{N}$ stress of seedlings by building a machine vision system to extract the object area of canopy [126]. Color image processing has been successfully applied to the diagnosis of crop N status and growth analysis [127-129], which can use digital cameras to get images in the visible light range that reflect the characteristics of the crop or soil background based on the $R, G$, and $B$ spectral information (Figure 4). Then we do further segmentation and feature extraction of the image, and select the appropriate estimation method to construct the $\mathrm{N}$ status estimation model. If the segmentation effect is not good, the original $R, G$, and $B$ bands can also be transformed into normalized color components, hue-saturation-intensity (HSI) space to improve the estimation accuracy in vegetation analysis [130].

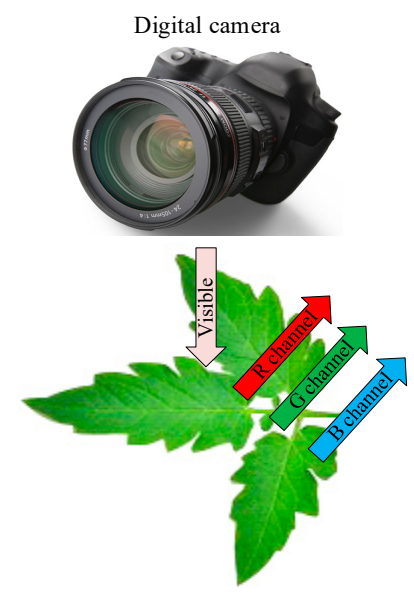

Figure 4. Basic principles of the machine vision technology.

\subsubsection{Application of Machine Vision System Selection to the Diagnosis of Crop N Status}

A digital camera is one of the main components of most machine vision systems, which is also used as a remote evaluation tool to monitor crop growth and $\mathrm{N}$ status by capturing crop images $[34,85,131]$. Moreover, hyperspectral and airborne miniaturized multispectral cameras have also been used to extract spectral and 3D features [132]. An artificial vision system (AVS) (HP Scanjet 3800) was developed for interpretation and analysis of images, which can acquire high quality images and estimate nutrient deficiency at different growth stages of crop, especially at the beginning of growth period, and may be helpful for early diagnosis and correction in the same growth cycle [24]. However, it cannot move flexibly. Tewari et al. [133] designed a manually operated four-wheel test trolley, which can flexibly acquire an outdoor color image feature of the crop under controlled illumination to estimate crop $\mathrm{N}$ status successfully in the field. Furthermore, some studies have proved that the combination of multiple diagnostic methods based on machine vision has a higher advantage in the assessment of $\mathrm{N}$ status, such as the combination of SPAD and machine vision [134,135] and the combination of spectroscopy and machine vision [136,137].

\subsubsection{Application of Visual Data Processing to the Diagnosis of Crop N Status}

The effective processing of visual data plays an important role in avoiding noise interference in the natural environment, such as soil, weeds, stones, dried, and semi-dried leaves in the image. One of the important steps of the image processing is to segment out various necessary regions and take it as the region of interest for decision-making of the crop $N$ status $[134,138]$. There are some segmentation algorithms for automatic image segmentation, such as spatially varying mean intensity 
values, mathematical morphology, nonlinear spatial filtering, $\mathrm{YCbCr}$ color and grayscale morphology, which can be used to separate the plant from the background [85]. In the canopy image segmentation, the magnitude and distribution of the difference value can be obtained by subtracting the red channel value from the green channel, and which can be set for segmentation, and then the relationship between the characteristic parameters and $\mathrm{N}$ content can be established [138]. At present, there are still many problems in image processing. On the one hand, the external light condition is always changing in the process of image acquisition, which makes it a challenging task in image processing [4]. The image segmentation method based on the neural network can remove unnecessary components from plant images and keep the leaves as the region of interest, which can effectively avoid the influence of light intensity on image acquisition [139]. On the other hand, the complexity of the images obtained in the field makes it difficult for the traditional RGB color system to obtain the segmentation results accurately. However, the Lab color system has robust illumination variations and large color ranges, providing better performance than RGB and other color systems [133]. Therefore, we can transform RGB images into the Lab system to extract the channel of $L$, $a$, and $b$, then used the Otsu method combined with morphological processing and median filtering to obtain a binary image. Among them, L-channel can be used to segment objects from other crops using luminance differences, to remove scattered pixels by using morphological operations and median filtering, then to obtain the final segmentation results [140].

Based on the segmented image, the RGB, Lab, HSI, and RLI channel information of the image is usually extracted for feature acquisition $[133,137]$. For example, a greenness index [141], some color feature parameters including dark green color index $(D G C I)$, value $(\mathrm{V})$ and hue $(\mathrm{H})$ [135], the spatial and temporal distributions of the color index of the canopy such as G, G/R, G/B, NRI, NGI, NBI [22] can also be used to acquire the crop N status. Among them, the NRI was regarded as a valid indicator that can better reflect on the $\mathrm{N}$ status of rice [134] and maize [142]. Besides, the total $\mathrm{N}$ status can influence the leaf color. A novel indicator named Growth Status (GS) was developed to reflect the crop growth conditions, which mainly includes $G S_{M E R}$ and $G S_{M C C}$ versions, more precision results can be obtained by combining this indicator with the color factors (color characteristics of leaf surface) [140]. The commonly used image feature parameters for $\mathrm{N}$ status diagnosis are summarized in Table 3. 
Table 3. Summary of different image feature for diagnosis of the $\mathrm{N}$ status.

\begin{tabular}{|c|c|c|c|}
\hline Indices & Abbreviations & Formula & Reference \\
\hline Red channel & $\mathrm{R}$ & - & [22] \\
\hline Green channel & G & - & [22] \\
\hline Blue channel & B & - & [22] \\
\hline G/R channel & $\mathrm{G} / \mathrm{R}$ & - & [22] \\
\hline G/Bchannel & $\mathrm{G} / \mathrm{B}$ & - & [22] \\
\hline The normalized difference index & NDI & $\mathrm{NDI}=(\mathrm{r}-\mathrm{g}) /(\mathrm{r}+\mathrm{g}+0.01)$ & [134] \\
\hline $\mathrm{GS}_{\mathrm{MER}}$ & $\mathrm{GS}_{\mathrm{MER}}$ & $\mathrm{GS}_{\mathrm{MER}}=\mathrm{S}_{\mathrm{P}} / \mathrm{MER}_{\mathrm{P}}$ & [138] \\
\hline $\mathrm{GS}_{\mathrm{MCC}}$ & $\mathrm{GS}_{\mathrm{MCC}}$ & $\mathrm{GS}_{\mathrm{MCC}}=\mathrm{S}_{\mathrm{P}} / \mathrm{MCC}_{\mathrm{P}}$ & [138] \\
\hline The normalized RGB values & $\begin{array}{l}\mathrm{r} \\
\mathrm{g} \\
\mathrm{b}\end{array}$ & $\begin{array}{l}\mathrm{r}=\mathrm{R} /(\mathrm{R}+\mathrm{G}+\mathrm{B}) \\
\mathrm{g}=\mathrm{G} /(\mathrm{R}+\mathrm{G}+\mathrm{B}) \\
\mathrm{b}=\mathrm{B} /(\mathrm{R}+\mathrm{G}+\mathrm{B})\end{array}$ & $\begin{array}{l}{[140]} \\
{[140]} \\
{[140]}\end{array}$ \\
\hline DGCI & DGCI & $\mathrm{DGCI}=\{[(\mathrm{H}-60) / 60]+(1-\mathrm{S})-(1-\mathrm{V})\} / 3$ & [140] \\
\hline Saturation & $\mathrm{S}$ & $\mathrm{S}=\{[\max (\mathrm{R}, \mathrm{G}, \mathrm{B})-\min (\mathrm{R}, \mathrm{G}, \mathrm{B})] / \max (\mathrm{R}, \mathrm{G}, \mathrm{B})\}$ & [140] \\
\hline Saturation & SAT & $\mathrm{SAT}=1-3 \min \{\mathrm{r}, \mathrm{g}, \mathrm{b}\}$ & [142] \\
\hline Intensity & INT & $\mathrm{INT}=(\mathrm{R}+\mathrm{G}+\mathrm{B}) / 3$ & [143] \\
\hline Hue & Hue & $\begin{array}{c}\text { Hue }=w \text { if } B \leq G \text { or Hue }=2 \pi-w \text { if } B>G \\
\text { where } w=\cos ^{-1}\left[\left[\{2 R-(G+B)\} / 2\{(R-G)(B-G)+(R-B)(G-B)\}^{0.5}\right]\right]\end{array}$ & [143] \\
\hline Canopy cover & $\mathrm{CC}$ & $\mathrm{CC}=(1+\mathrm{L})((\mathrm{G}-\mathrm{R}) /(\mathrm{G}+\mathrm{R}+\mathrm{L}))$ & [144] \\
\hline $\begin{array}{l}\text { The normalized difference between the R, } \\
\qquad \text { G, and B channels }\end{array}$ & $\begin{array}{l}\text { NGMR } \\
\text { NGMB } \\
\text { NRMB }\end{array}$ & $\begin{aligned} \mathrm{NGMR} & =(\mathrm{G}-\mathrm{R}) /(\mathrm{G}+\mathrm{R}) \\
\mathrm{NGMB} & =(\mathrm{G}-\mathrm{B}) /(\mathrm{G}+\mathrm{B}) \\
\mathrm{NRMB} & =(\mathrm{R}-\mathrm{B}) /(\mathrm{R}+\mathrm{B})\end{aligned}$ & $\begin{array}{l}{[145]} \\
{[145]} \\
{[145]} \\
\end{array}$ \\
\hline $\begin{array}{l}\text { The ratios between the } \mathrm{R}, \mathrm{G}, \\
\text { and } \mathrm{B} \text { channels }\end{array}$ & $\begin{array}{l}\text { GDR } \\
\text { GDB } \\
\text { RDB }\end{array}$ & $\begin{aligned} \mathrm{GDR} & =\mathrm{G} / \mathrm{R} \\
\mathrm{GDB} & =\mathrm{G} / \mathrm{B} \\
\mathrm{RDB} & =\mathrm{R} / \mathrm{B}\end{aligned}$ & $\begin{array}{l}{[145]} \\
{[145]} \\
{[145]}\end{array}$ \\
\hline
\end{tabular}

$\bar{R}, \mathrm{G}$, and B are the real pixel values of RGB channel of images, respectively; $P_{S C}$ represents the percentage of pixels in the canopy under sunlight, $P_{S H C}$ represents the percentage of pixels in the canopy under shadow, $\mathrm{P}_{\mathrm{SS}}$ represents the percentage of pixels in the soil under sunlight, $\mathrm{P}_{\mathrm{SHS}}$ represents the percentage of pixels in the soil under shadow; the minimum circumscribed circle $\left(\mathrm{MCC}_{\mathrm{p}}\right)$, the minimum enclosing rectangle $\left(\mathrm{MER}_{\mathrm{p}}\right)$; $\mathrm{L}$ is the soil baseline, the whole canopy is 0 , and the bare soil is 1 . 
Furthermore, previous studies [146] have also demonstrated that texture and color are the main visual features related to maize N status. There have some methods such as Gabor Wavelet (GW), Volumetric Fractal Dimension (VFD), and VFD with canonical analysis (VFDCA) for the texture analysis [24]. For instance, some non-destructive methods were proposed to extract 11 crop features from digital images, including a morphological feature (top projected canopy area), color features (the value of R, G, B, H, S, I), and textural features (entropy, contrast, homogeneity, and energy) [137,147]. Besides, as the shape and color of leaves dynamically change with the amount of fertilizer applied, some new feature parameters such as shape features (etiolation degree (ED), etiolation area (EA)), color features (normalized red or green index, etc.), and morphological features (perimeter, area) were proposed and used to assess the process of leaf change, which has a good potential in crop $\mathrm{N}$ status estimation $[148,149]$. However, sometimes, color and texture features will be misjudged due to the influence of external light. Therefore, this is a situation that needs to be considered to ensure the accuracy of the estimation model.

\subsubsection{Application of Estimation Methods Based on Vision Data to Crop N Status Diagnosis}

It is a critical task to select an appropriate estimation method for establishing a robust estimation model, which can assess crop N status. Compared with the statistical method, ANN has good potential to process data. In particular, when the image feature is multifarious, and the original data do not follow a similar distribution pattern [150-152]. For example, based on R, G, B channels of the color image obtained from a digital camera, a linear regression model and ANNs model named the multilayer perception neural network (MLPNN) was established and the result showed that the MLPNN model has better accuracy than the linear regression model [153]. As a popular algorithm, PLSR was used when processing multivariable data, and many studies have demonstrated that this method is powerful for acquiring key variables and establishing an accurate regression model $[154,155]$, which is effective in estimating water and $\mathrm{N}$ status of winter wheat [145]. Moreover, combinations of algorithms are also common. The random forest (RF) was used as the estimator for crop N status and biomass estimation, and simple linear regression (SLR) was used for validating the consistency of the results of RF [132]. However, when there is a large amount of data, the above methods have some limitations in calculation efficiency and model accuracy. In this case, it is difficult to ensure the accuracy and real-time of crop $\mathrm{N}$ status assessment. With the development of deep learning in image processing, an ensemble of deep learning multilayer perceptron was proposed by using committee machines, which can be used for color normalization and image segmentation, and combine with a genetic algorithm (an optimization algorithm) to fine-tune the color normalization and achieve a good result in crop $\mathrm{N}$ estimation [156]. Among them, the principle of image processing and $\mathrm{N}$ status evaluation of this method is shown in Figure 5. Compared with linear regression, non-linear regression, and neural network, the deep learning method has higher training accuracy, but it requires a lot of data. When the amount of data is small, it is likely that the training results have been fitted. Therefore, in the later process of algorithm selection, we should choose whether to use a deep learning method according to the size of the data.

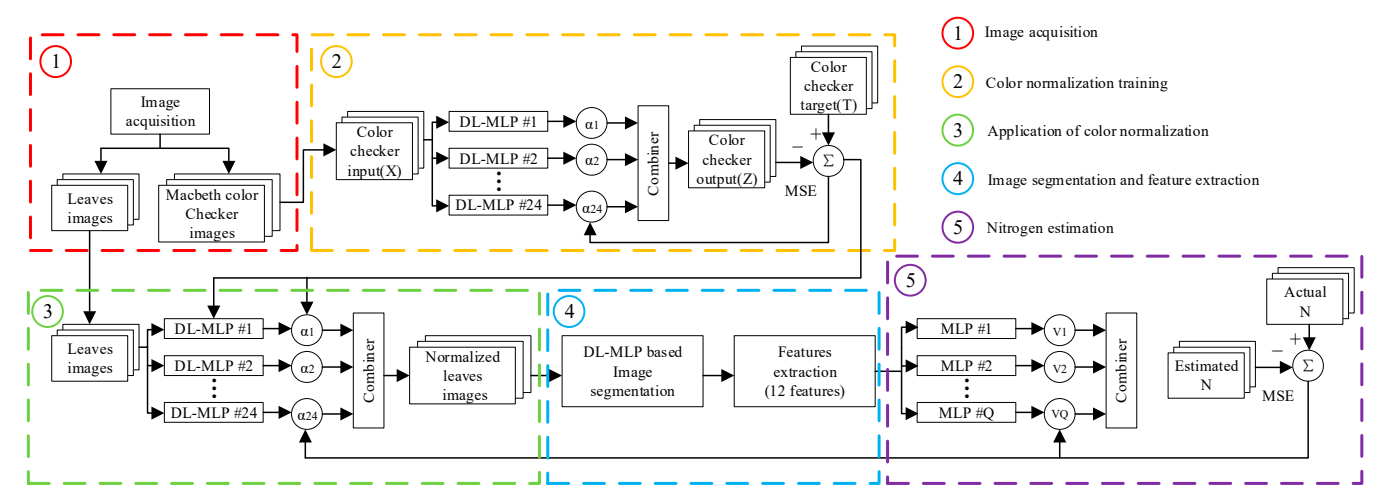

Figure 5. Method based on deep learning for on-field N status estimation in plants. 
In summary, vision technology has been widely used in agricultural research due to its advantages of low cost and high precision, such as crop $\mathrm{N}$ status diagnosis and $\mathrm{N}$ stress research. However, the phenotypic phenomenon of leaves is not very obvious in the early stage of $\mathrm{N}$ deficiency, and it is difficult to catch the early symptoms of $\mathrm{N}$ deficiency by using visual technology. However, when $\mathrm{N}$ deficiency occurs seriously, although visual technology can realize low-cost identification, but the crop has been under serious stress, this affects crop yield and quality. In addition, most of the data involved in the visual technology are image data, so the traditional methods have some limitations, such as low efficiency and large amount of calculation. Although the deep learning method has a good effect on image data, it has certain requirements on the amount of data, and it is difficult to obtain large-scale image data in $\mathrm{N}$ diagnosis. With the development of crop phenotype technology, the research and application of phenotype platform will be able to solve this problem, and it can be used to obtain the image data of the whole growth stage of crops for the evaluation of crop $\mathrm{N}$ status.

\section{Discussion: Advantages, Challenges, and Perspectives}

\subsection{The Advantages of N Non-Destructive Diagnosis}

\subsubsection{Advantages in Quantitative Analysis of N Status}

Hyperspectral techniques have a great potential in quantitative diagnosis of crop N status [157]. For example, derivative spectrum has its unique advantages in spectral analysis [50,51,152]. First, it can not only improve the resolution of the spectrum, but also separate the absorption peaks from the overlapping absorption spectrum, and carry out quantitative analysis separately. Second, derivative spectrum can eliminate or reduce the interference of background absorption, and it can be used for samples with serious background absorption interference, the derivative spectrum can also be used for accurate quantitative analysis; finally, the derivative spectrum can also accurately determine the position of the absorption peak ( $\lambda$ max), and can improve the signal-to-noise ratio and detection sensitivity. Besides, nitrogen nutrition index (NNI), the ratio of the crop's actual $\mathrm{N}$ concentration to the critical $\mathrm{N}$ concentration has been regarded as an effective index for diagnosing crop $\mathrm{N}$ status [27,158-163]. When the value of NNI is 1 , it means that the N status of crops is in the optimal state. When NNI $>1$ and $\mathrm{NNI}<1$, it means that crops are in the state of over nutrition and under nutrition, respectively. NNI can also distinguish crop $\mathrm{N}$ status by comparing the shoot $\mathrm{N}$ content (SNC) with plant $\mathrm{N}$ content (PNC). Meanwhile, there are positive relationships between $\mathrm{N}$ requirement, yield, grain quality, photosynthesis, chlorophyll meter readings, N use efficiency, crop N partition with NNI [158,164,165], and the result showed a good performance between NNI and above-mentioned indices. In addition, the UAV multispectral images can provide rich texture features [52,97], which can improve the accuracy of NNI estimation and has great potential for crop N-status monitoring on local scales. Therefore, NNI can be used as a good quantitative analysis index to analyze the $\mathrm{N}$ status of crops. Although machine vision technology is also used for accurate assessment of crop $\mathrm{N}$ status, the accuracy of $\mathrm{N}$ diagnosis is low due to the influence of external light, leaf occlusion, and leaf shape [4]. Therefore, in future quantitative diagnosis research, the spectral technology shows better performance. Meanwhile, it can be considered to combine multiple spectral indexes or develop more accurate spectral indexes suitable for most crops for quantitative evaluation of crop $\mathrm{N}$ status.

\subsubsection{Advantages in Qualitative Analysis of N Status}

Early recognition of crops under $\mathrm{N}$ stress is critical for nutrition management during the whole growing season of the crops [166]. Therefore, timely detection of $\mathrm{N}$ stress in crops is essential. $\mathrm{N}$ is usually distributed in a vertical gradient in the crop. When the crop is deficient in $\mathrm{N}$, it first appears in the lower leaf, the $\mathrm{N}$ status of the lower leaf is more sensitive to the spectral reflectance and significantly related to the soil $\mathrm{N}$ level [114]. Meanwhile, the relevant study found that the lowest two leaves of the crop can be used to indicate the crop N deficiency and guide fertilization [167], 
which would change regularly with the degree of $\mathrm{N}$ stress and reflect the amount of $\mathrm{N}$ applied. Under the stress of $\mathrm{N}$ deficiency, the leaves of the early stage of the crop showed chlorosis, and the leaves gradually dried and necrotic [168]. With the increase of $\mathrm{N}$ application, the $\mathrm{N}$ uptake and biomass of the plant also increase. When the crop grows under the excessive or optimum $\mathrm{N}$ supply conditions, the availability of $\mathrm{N}$ in the root culture medium directly determines the crop uptake of $\mathrm{N}$ and has nothing to do with the growth rate potential [72]. When the $\mathrm{N}$ application amount reaches the critical value, the biomass of crops will not increase. Therefore, the identification of sensitive leaves and the determination of effective indicators are two main tasks for achieving precise fertilization of crops. However, the evaluation of plant stress is usually done by chemical analysis or visual evaluation. Although the accuracy is high, the sampling process is time-consuming and remedial measures are not allowed in practice. The cost of visual diagnosis is low, the visual symptoms caused by some pest attacks and diseases are very similar to those caused by $\mathrm{N}$ stress. Therefore, it is easy to make mistakes in interpretation. In future qualitative diagnosis research, in order to reduce the cost of research, it is necessary to develop more advanced machine vision algorithm to accurately identify the visual symptoms caused by pests and $\mathrm{N}$ stress. At that time, vision technology is expected to become a low-cost, fast, and accurate tool for qualitative research of crop $\mathrm{N}$ status.

\subsection{The Challenges of N Non-Destructive Diagnosis}

\subsubsection{Challenges of Crop Characteristics on N Status Non-Destructive Diagnosis}

Canopy reflectance is mainly obtained from the leaves of crops, and it is difficult to obtain the signals of the stems and panicles after heading stage. Therefore, it has some limitations to evaluate the $\mathrm{N}$ status of crops. Fortunately, there have been some studies that estimate the photo $\mathrm{N}$ status of crop leaves, stems, and shoots $[169,170]$. Furthermore, due to the water absorption of fresh leaves in the short-wave infrared region (SWIR), the signals of $\mathrm{N}$ is weaker in the whole spectra $[93,171]$. Therefore, the reflection spectrum of fresh leaves in the short-wave infrared region is rarely used for $\mathrm{N}$-content estimation, and this has been proven in $[99,100,102,172,173]$. However, if the crop is under long-term water stress, the canopy structure, such as leaf area index and average leaf inclination, will show obvious differences and affect the diagnosis of crop canopy $\mathrm{N}$ status. Besides, due to the different leaf shapes of different crops (corn, potato, tomato, sugarcane, etc.), there are obvious differences in the $\mathrm{N}$ status of crops in different growth cycles $[3,10,21,170]$. Some studies [135] have shown that the middle part of rice leaves is more appropriate for $\mathrm{N}$ diagnosis than the tip and the base of leaves. At the same time, the tillering stage and booting stage is an important diagnostic period for evaluating the $\mathrm{N}$ status of rice. Furthermore, careful repeated replication and plant selection can also effectively overcome the inherent heterogeneity of leaf level measurement in the process of diagnosis. Therefore, it is especially critical to select a suitable measurement location and measurement period.

\subsubsection{Challenges of External Environment Conditions on N Non-Destructive Diagnosis}

The canopy reflectance, which is widely used at present, can be used for spectral sampling of a plant population or community, rather than for a single plant. Therefore, it can be used for fast and accurate estimation of the growth status and spatial variability of large-area crops. Meanwhile, canopy reflectance can be used to separate $\mathrm{N}$ and water stress signals [174]. However, because of the influence of atmospheric, biophysical properties of the vegetation, soil background, and the difference of canopy structure of different crops, the overlapping of the canopy leaves and the shadow occlusion problem have affected the effect of canopy spectral diagnosis to some extent [175]. Therefore, canopy spectroscopy technology should comprehensively consider various influencing factors, so as to achieve the goal of high-precision diagnosis. Furthermore, it is more challenging to evaluate the canopy $\mathrm{N}$ status under the cross season (location) conditions due to the difference between canopy coverage and soil background and the dilution effect of canopy $\mathrm{N}$ in the field of view of the sensor. Due to the limitations of low spatial coverage and adverse weather conditions, the $\mathrm{N}$ estimation ability of 
ground-based platforms is often limited. Most of the imaging systems mostly adopt top view or side view imaging mode, but it is difficult to obtain the complete plant structure because of the leaf shading, which further affects the estimation accuracy of biomass such as $\mathrm{N}$ [40]. Therefore, an ideal shooting angle is very important, and there are significant differences in the response to different biomass at different angles, further details about the shooting angle was provided by Zhang et al. [176]. Therefore, in future research, it is very necessary to avoid the influence of external environment to realize the accurate assessment of crop $\mathrm{N}$ status.

\subsubsection{Challenges of the Choice of Diagnostic Technology on N Non-Destructive Diagnosis}

The reflectivity properties of the canopy light mainly come from the light absorption of specific wavelengths, which is related to some specific characteristics (canopy structure, canopy coverage, etc.) of the plant itself [177]. Protein in plant leaves show obvious absorption characteristics in short wave near-infrared region and visible light region, absorption by chlorophyll is mainly in the blue and red wavelengths in the VIS, which is caused by the conjugated C-C single bond and double bonds functional group of porphyrin ring, C-N bonds, N-H bonds, and C-H bonds in molecular phytic acid [178,179]. Meanwhile, the accurate diagnosis of crop $\mathrm{N}$ status is based on obtaining more crop information. Spectral technology can obtain more leaf surface information than fluorescence technology, this shows why spectroscopy has great potential in estimating $\mathrm{N}$ status of crops. For instance, the vertical $\mathrm{N}$ distribution of crops will have an impact on the spectral reflectance of the whole canopy [115], which cannot be detected only through the nadir observation, and the multi-angle observation contains more information than the nadir observation. Therefore, multi-angle optical remote sensing technology is used as a potential solution to solve this problem because it can assess the three-dimensional structure of vegetation, and this technology realizes the monitoring of $\mathrm{N}$ status in the middle and bottom leaves of crops, so as to provide precise fertilization guidance. However, if the canopy of crops tends to be completely closed in the growth process, the above technology will not achieve the expected advantages and effects. In future research, in order to achieve accurate monitoring of crop N status, the research of the stereo spectrum monitoring system will become possible.

$\mathrm{N}$ deficiency of plants will cause changes in their own color, shape, and texture [180]. Related studies have shown that $\mathrm{N}$ status may influence the level of endogenous phytohormones, such as cytokinin [181], which play a regulatory role in cell division, cell elongation, and morphogenesis of plants. Generally, the lack of $\mathrm{N}$ in plants is mainly recognized by the change of leaf color [24,182], and the most obvious symptom is that the loss of chlorophyll caused by the lack of $\mathrm{N}$ makes the leaves yellow $[177,183]$. Furthermore, changes in leaf surface texture (entropy, contrast, homogeneity, and energy) may occur due to changes in leaf surface yellowish appearance and structure [184]. As a low-cost diagnostic technology, vision technology is suitable for the monitoring and discrimination of leaf surface characteristics. However, these changes in shape, texture, and color are not obvious at the beginning of $\mathrm{N}$ deficiency, which only indirectly reflects the severity of crop $\mathrm{N}$ deficiency. Therefore, spectral technology can more accurately show the N status of crops. Most image-based methods for estimating crop $\mathrm{N}$ status are carried out in a controlled environment with an artificial lighting system [185], which needs additional equipment to assist in $\mathrm{N}$ status estimation, so it is time-consuming and not practical. Although the rice $\mathrm{N}$ status of different varieties and different growth stages have been monitored under natural light conditions by using digital color image analysis technology [4], it is still a difficult task to assess the $\mathrm{N}$ status of crops by vision technology because of the influence of light intensity change and plant leaf shadow in the field. In addition, most crops have different performance under $\mathrm{N}$ stress, such as lettuce [180], which has complex dynamic changes, including both external attributes (color, morphology, texture) and internal attributes (protein, chlorophyll). Furthermore, plants may also exhibit similar external symptoms under different stress conditions [184]. Single inspection technology has some limitations, computer vision cannot recognize the chemical properties of plants, spectroscopy cannot detect the spatial information of the plant population [186,187]. 
Therefore, in future research, multi-technology combination and multi-information fusion will have great potential in crop $\mathrm{N}$ status diagnosis.

For the selection of diagnosis technology, in addition to the above accuracy considerations, we should also consider another important factor: use scenarios. For small farms, the cost and ease of use of diagnostic technology are two key factors. On the one hand, although some diagnostic techniques have high accuracy, they are too expensive to be used in small farms. On the other hand, some diagnostic technologies are more suitable for scientific research, and they have certain technical requirements for users in the use process. For example, most sensors provide the value of different measurements at the same moment, and then use different mathematical equations to calculate the target value of measurements. However, most farmers are not trained in this field, so it is difficult to realize. For the large-scale farms, because of the large planting area, the use of remote sensing, UAV, and other large-scale crop nutrition status and growth monitoring tools has the advantages of wide range of data acquisition and high real-time. At the same time, the production and operation of large-scale farms are relatively standardized, most of the staff have received professional training, and the overall economic strength is strong, which can meet the requirements of some diagnostic techniques.

\subsection{Application Prospects of Non-Destructive Diagnosis in N Management}

Precision agriculture is the main trend of modern agriculture development, which mainly involves the precise application of fertilizers and nutrients. Compared with the traditional uniform application of fertilizers, precision agriculture divides land management regions according to different soil types, specific locations, and management histories [188]. On the one hand, the quantitative information on crop $\mathrm{N}$ status is very critical for fertilization decisions [3]. As one of the most important nutrients for crop growth, the $\mathrm{N}$ directly determines grain quality and crop yield [189]. Therefore, to minimize the cost and loss of $\mathrm{N}$ fertilizer caused by excessive fertilization, $\mathrm{N}$ fertilizer should be applied accurately according to the crops' requirements in each growth stage. The estimation of crop $\mathrm{N}$ status is mainly based on the actual growth conditions of crops, which can reduce the uncertainty of soil conditions [190]. At present, there are many studies on the diagnosis of in-season $\mathrm{N}$ status by using remote sensing or other real-time analysis methods [191]. However, due to the unpredictable weather patterns and the dynamics of $\mathrm{N}$ transformation in the soil, $\mathrm{N}$ loss has great variability, so it is difficult to estimate the $\mathrm{N}$ requirement of in-season crops [192]. It is of great significance for crop yield and environmental protection to adopt dynamic fertilization technology based on the balance of crop $\mathrm{N}$ supply and requirement [193], and this technology can be realized by fine-tuning the fertilization rate according to the $\mathrm{N}$ status of each growth stage of the crop [29]. Therefore, how to estimate the $\mathrm{N}$ status of crop leaves and the overall $\mathrm{N}$ deficiency is one of the key technologies to achieve dynamic and accurate fertilization. Existing studies [109] have shown that dry weight above ground, $\mathrm{N}$ accumulation, and LAI are good indicators of $\mathrm{N}$ status and crop growth, providing useful and important information for accurate $\mathrm{N}$ fertility management and crop yield estimation. With the support of information (quantity and quality) on crops, farmers can plan the nutrient application and crop protection in a reasonable way [194]. The active sensor-based method has good potential for enhancing crop $\mathrm{N}$ management [195]. On the other hand, crop $\mathrm{N}$ uptake is also a good indicator of crop $\mathrm{N}$ status. A method was proposed to predict crop $\mathrm{N}$ uptake by determining the optimal bandwidth, central wavelength, and vegetation indices [196], which was critical for estimation of crop N uptake more accurately and precisely in crop management [72]. Therefore, the diagnosis of in-season $\mathrm{N}$ status and the estimation of $\mathrm{N}$ requirement are the key to the precise fertilization management of crops. Although many studies focused on the diagnosis of crop seasonal $\mathrm{N}$ status, few related $\mathrm{N}$ status to crop $\mathrm{N}$ requirement or topdressing $\mathrm{N}[61,197]$. In further research, in order to make up for the difference between the $\mathrm{N}$ nutrition status and $\mathrm{N}$ requirement of crops, we should consider establishing more precise estimation models or develop a novel active canopy sensor with good application prospects and universality for crop $\mathrm{N}$ uptake estimation based on hyperspectral sensing data. 


\section{Conclusions and Recommendations}

We systematically reviewed the state-of-the-art of non-destructive optical methods for monitoring the $\mathrm{N}$ status of crops, and summarized their advantages and disadvantages from the perspective of system selection, data processing, and estimation methods. We found that the spectral method has a significant advantage in the quantitative study of crop $\mathrm{N}$ status, while visual technology is more efficient in the qualitative study of nitrogen.

Diagnosis technology is the basis of an accurate diagnosis of crop N status. Although spectral and machine vision technologies have some significant advantages over traditional ones, they still have some drawbacks due to the interference of factors, e.g., light, soil, and canopy. Each optical technology has its unique advantages, so better results can be achieved through the combination of optical technologies. For example, the fusion of spectroscopy and visual technology can diagnose the intrinsic properties of the leaves, and as well accurately evaluate the N nutrition status of the crops, based on the color and texture characteristics exhibited by the leaves. Therefore, further improvements are needed for the fusion of multiple diagnostic techniques in future studies.

The timeliness of the data processing and estimation methods are critical for the accurate diagnosis of crop $\mathrm{N}$ status, and $\mathrm{N}$ requirements of crops vary during whole growth stages. Therefore, multi information fusion real-time processing and innovation of time series estimation methods can be considered to improve the diagnosis accuracy of crop $\mathrm{N}$ status in future research.

Author Contributions: Conceptualization, P.Z. and D.L.; formal analysis, P.Z.; software, P.Z.; supervision, D.L.; writing-original draft, P.Z.; writing-review and editing, P.Z., D.L., T.C. and W.Q. All authors have read and agreed to the published version of the manuscript.

Funding: This work was supported by the National Key R\&D Program "Advancing digital precision aquaculture in China (ADPAC)" [Grant no.2017YFE0122100]; The Institute of fishery machinery and instruments, Chinese Academy of Fishery Sciences Program “Research of Intelligent Model and Precision Control Key Technologies in Facilities Aquaculture" [Grant no.2017YFD0701702]; The Guolian Aquatic Products Development Co. LTD Program "Big data analysis and management cloud service platform construction and large-scale application of shrimp" [Grant no.2017B010126001].

Acknowledgments: The authors would like to thank the editor and reviewers for their valuable input, time, and suggestions to improve the quality of the manuscript.

Conflicts of Interest: The authors declare no conflict of interest. The funders had no role in the design of the study; in the collection, analyses, or interpretation of data; in the writing of the manuscript, or in the decision to publish the results.

\section{References}

1. Kraiser, T.; Gras, D.E.; Gutiérrez, A.G.; González, B.; Gutiérrez, R.A. A holistic view of nitrogen acquisition in plants. J. Exp. Bot. 2011, 62, 1455-1466. [CrossRef] [PubMed]

2. Mcallister, C.H.; Beatty, P.H.; Good, A.G. Engineering nitrogen use efficient crop plants: The current status. Plant Biotechnol. J. 2012, 10, 1011-1025. [CrossRef] [PubMed]

3. Gianquinto, G.; Orsini, F.; Fecondini, M.; Mezzetti, M.; Sambo, P.; Bona, S. A methodological approach for defining spectral indices for assessing tomato nitrogen status and yield. Eur. J. Agron. 2011, 35, $135-143$. [CrossRef]

4. Wang, Y.; Wang, D.; Shi, P.; Omasa, K. Estimating rice chlorophyll content and leaf nitrogen concentration with a digital still color camera under natural light. Plant Methods 2014, 10, 36. [CrossRef]

5. Kaushal, S.S.; Groffman, P.M.; Band, L.E.; Elliott, E.M.; Shields, C.A.; Carol, K. Tracking nonpoint source nitrogen pollution in human-impacted watersheds. Environ. Sci. Technol. 2011, 45, 8225-8232. [CrossRef]

6. Inoue, Y.; Sakaiya, E.; Zhu, Y.; Takahashi, W. Diagnostic mapping of canopy nitrogen content in rice based on hyperspectral measurements. Remote Sens. Environ. 2012, 126, 210-221. [CrossRef]

7. Cui, M.; Zeng, L.; Qin, W.; Feng, J. Measures for reducing nitrate leaching in orchards:A review. Environ. Pollut. 2020, 263, 114553. [CrossRef]

8. Ishijima, K.; Sugawara, S.; Kawamura, K.; Hashida, G.; Morimoto, S.; Murayama, S.; Aoki, S.; Nakazawa, T. Temporal variations of the atmospheric nitrous oxide concentration and its $\delta 15 \mathrm{~N}$ and $\delta 18 \mathrm{O}$ for the 
latter half of the 20th century reconstructed from firn air analyses reconstructed from firn air analyses. J. Geophys. Res. Atmos. 2007, 112. [CrossRef]

9. Yasin, G. Optical Sensors-New Developements and Practical Applications; Intech Book: London, UK, 2014.

10. Miphokasap, P.; Honda, K.; Vaiphasa, C.; Souris, M.; Nagai, M. Estimating canopy nitrogen concentration in sugarcane using field imaging spectroscopy. Remote Sens. 2012, 4, 1651-1670. [CrossRef]

11. Miao, Y.; Mulla, D.J.; Randall, G.W.; Vetsch, J.A.; Vintila, R. Combining chlorophyll meter readings and high spatial resolution remote sensing images for in-season site-specific nitrogen management of corn. Precis. Agric. 2009, 10, 45-62. [CrossRef]

12. Zhang, C.; Kovacs, J.M.; Wachowiak, M.P.; Flores-Verdugo, F. Relationship between Hyperspectral Measurements and Mangrove Leaf Nitrogen Concentrations. Remote Sens. 2013, 5, 891-908. [CrossRef]

13. Turner, F.T.; Jund, M.F. Assessing the nitrogen requirements of rice crops with a chlorophyll meter. Anim. Prod. Sci. 1994, 34, 1001-1005. [CrossRef]

14. Wang, S.; Zhu, Y.; Jiang, H.; Cao, W. Positional differences in nitrogen and sugar concentrations of upper leaves relate to plant $\mathrm{N}$ status in rice under different $\mathrm{N}$ rates. Field Crop. Res. 2006, 96, 224-234. [CrossRef]

15. Feng, W.; Yao, X.; Zhu, Y.; Tian, Y.C.; Cao, W.X. Monitoring leaf nitrogen status with hyperspectral reflectance in wheat. Eur. J. Agron. 2008, 28, 394-404. [CrossRef]

16. Prabhakar, M.; Prasad, Y.G.; Thirupathi, M.; Sreedevi, G.; Dharajothi, B.; Venkateswarlu, B. Use of ground based hyperspectral remote sensing for detection of stress in cotton caused by leafhopper (Hemiptera: Cicadellidae). Comput. Electron. Agric. 2011, 79, 189-198. [CrossRef]

17. Weiss, M.; Jacob, F.; Duveiller, G. Remote sensing for agricultural applications: A meta-review. Remote Sens. Environ. 2020, 236, 111402. [CrossRef]

18. Yu, Z.; Cao, Z.; Wu, X.I.; Bai, X.; Qin, Y.; Wen, Z.; Yang, X.; Zhang, X.; Xue, H. Automatic image-based detection technology for two critical growth stages of maize: Emergence and three-leaf stage. Agric. For. Meteorol. 2013, 174-175, 65-84. [CrossRef]

19. Haboudane, D.; Miller, J.R.; Pattey, E.; Zarco-Tejada, P.J.; Strachan, I.B. Hyperspectral vegetation indices and novel algorithms for predicting green LAI of crop canopies: Modeling and validation in the context of precision agriculture. Remote Sens. Environ. 2004, 90, 337-352. [CrossRef]

20. Mayfield, A.H.; Trengove, S.P. Grain yield and protein responses in wheat using the N-Sensor for variable rate N application. Crop Pasture Sci. 2009, 60, 818-823. [CrossRef]

21. Raun, W.R.; Solie, J.B.; Taylor, R.K.; Arnall, D.B.; Mack, C.J.; Edmonds, D.E. Ramp Calibration Strip Technology for Determining Midseason Nitrogen Rates in Corn and Wheat. Agron. J. 2008, 100, 1088-1093. [CrossRef]

22. Dorigo, W.A.; Zurita-Milla, R.; Wit, A.J.W.; De Brazile, J.; Singh, R.; Schaepman, M.E. A review on reflective remote sensing and data assimilation techniques for enhanced agroecosystem modeling. Int. J. Appl. Earth Obs. Geoinf. 2007, 9, 165-193. [CrossRef]

23. Lee, K.J.; Lee, B.W. Estimation of rice growth and nitrogen nutrition status using color digital camera image analysis. Eur. J. Agron. 2013, 48, 57-65. [CrossRef]

24. Romualdo, L.M.; Luz, P.H.C.; Devechio, F.F.S.; Marin, M.A.; Zúñiga, A.M.G.; Bruno, O.M.; Herling, V.R. Use of artificial vision techniques for diagnostic of nitrogen nutritional status in maize plants. Comput. Electron. Agric. 2014, 104, 63-70. [CrossRef]

25. Saberioon, M.; Amin, M.S.M.; Gholizadeh, A.; Ezri, M.H. A review of optical methods for assessing nitrogen contents during rice growth. Appl. Eng. Agric. 2014, 30, 657-669.

26. Available online: https://www.potatogrower.com/2018/04/new-product-isaria-nutrient-sensor (accessed on 9 April 2018).

27. Muñoz-Huerta, R.F.; Guevara-Gonzalez, R.G.; Contreras-Medina, L.M.; Torres-Pacheco, I.; Prado-Olivarez, J.; Ocampo-Velazquez, R.V. A review of methods for sensing the nitrogen status in plants: Advantages, disadvantages and recent advances. Sensors 2013, 13, 10823-10843. [CrossRef]

28. Padilla, F.M.; Peña-Fleitas, M.T.; Gallardo, M.; Thompson, R.B. Proximal optical sensing of cucumber crop N status using chlorophyll fluorescence indices: The journal of the European Society for Agronomy. Eur. J. Agron. 2016, 73, 83-97. [CrossRef]

29. Padilla, F.M.; Gallardo, M.; Peña-Fleitas, M.T.; De Souza, R.; Thompson, R.B. Proximal optical sensors for nitrogen management of vegetable crops: A review. Sensors 2018, 18, 2083. [CrossRef] 
30. Chlingaryan, A.; Sukkarieh, S.; Whelan, B. Machine learning approaches for crop yield prediction and nitrogen status estimation in precision agriculture: A review. Comput. Electron. Agric. 2018, 151, 61-69. [CrossRef]

31. Thompson, R.B.; Tremblay, N.; Fink, M.; Gallardo, M.; Padilla, F.M. Tools and strategies for sustainable. nitrogen fertilisation of vegetable crops. In Advances in Research on Fertilization Management in Vegetable Crops; Tei, F., Nicola, S., Benincasa, P., Eds.; Springer: Berlin/Heidelberg, Germany, 2017; pp. 11-63.

32. Cao, Q.; Miao, Y.; Wang, H.; Huang, S.; Cheng, S. Non-destructive estimation of rice plant nitrogen status with crop circle multispectral active canopy sensor. Field Crops Res. 2013, 154, 133-144. [CrossRef]

33. Tremblay, N.; Fallon, E.; Bélec, C.; Tremblay, G.; Thibault, E. Growing season and soil factors related to predicting corn nitrogen fertilization in Quebec. Managing Crop Nitrogen for Weather; International Plant Nutrition Institute Norcross: Peachtree Corners, GA, USA, 2007; pp. 1-12.

34. Sakamoto, T.; Gitelson, A.A.; Nguyrobertson, A.L.; Arkebauer, T.J.; Wardlow, B.D. An alternative method using digital cameras for continuous monitoring of crop status. Agric. For. Meteorol. 2012, 154, 113-126. [CrossRef]

35. Available online: https://ohioline.osu.edu/factsheet/fabe-55202 (accessed on 25 May 2018).

36. Usha, K.; Singh, B. Potential applications of remote sensing in horticulture-A review. Sci. Hortic. 2013, 153, 71-83. [CrossRef]

37. Hansen, P.M.; Schjoerring, J.K. Reflectance measurement of canopy biomass and nitrogen status in wheat crops using normalized difference vegetation indices and partial least squares regression. Remote Sens. Environ. 2003, 86, 542-553. [CrossRef]

38. Huang, Z.; Turner, B.J.; Dury, S.J.; Wallis, I.R.; Foley, W.J. Estimating foliage nitrogen concentration from HYMAP data using continuum removal analysis. Remote Sens. Environ. 2004, 93, 18-29. [CrossRef]

39. Abdel-Rahman, E.M.; Ahmed, F.B.; Berg, M. Van Den Estimation of sugarcane leaf nitrogen concentration using in situ spectroscopy. Int. J. Appl. Earth Obs. Geoinf. 2010, 12, S52-S57. [CrossRef]

40. Lin, D.; Wei, G.; Shi, S.; Jian, Y.; Jia, S.; Bo, Z.; Song, S. Estimation of rice leaf nitrogen contents based on hyperspectral LIDAR. Int. J. Appl. Earth Obs. Geoinf. 2016, 44, 136-143.

41. Lin, D.; Wei, G.; Jian, Y. Application of spectral indices and reflectance spectrum on leaf nitrogen content analysis derived from hyperspectral LiDAR data. Opt. Laser Technol. 2018, 107, 372-379.

42. Wang, W.; Yao, X.; Tian, Y.; Liu, X.; Ni, J.; Cao, W.; Zhu, Y. Common Spectral Bands and Optimum Vegetation Indices for Monitoring Leaf Nitrogen Accumulation in Rice and Wheat. J. Integr. Agric. 2012, 11, 2001-2012. [CrossRef]

43. Bausch, W.C.; Khosla, R. QuickBird satellite versus ground-based multi-spectral data for estimating nitrogen status of irrigated maize. Precis. Agric. 2010, 11, 274-290. [CrossRef]

44. Maleki, M.; Massah, J.; Dehghan, M. Application of a spectral sensor for the assessment of nitrogen content in lettuce plants. Aust. J. Crop Sci. 2012, 6, 918-923.

45. Yang, H.Q.; Lv, G. Application of Multi-Spectral Imaging Technique in the Determination of Leaves Nitrogen Level of Fruit Tree. Adv. Mater. Res. 2011, 181-182, 272-275. [CrossRef]

46. Zhao, R.; Li, M.; Li, S.; Ding, Y. Winter wheat nutrition diagnosis under different $\mathrm{N}$ treatments based on multispectral images and remote sensing. Multispectral Hyperspectral Ultraspectral Remote Sens. Technol. Tech. Appl. III 2010, 7857, 78571G.

47. Zheng, H.; Cheng, T.; Li, D.; Yao, X.; Tian, Y.; Cao, W.; Zhu, Y. Combining unmanned aerial vehicle (UAV)-based multispectral imagery and ground-based hyperspectral data for plant nitrogen concentration estimation in rice. Front. Plant Sci. 2018, 9, 936. [CrossRef] [PubMed]

48. Liu, Y.L.; Qiang, L.; He, S.L.; Yi, S.L.; Liu, X.F.; Xie, R.J.; Zheng, Y.Q.; Deng, L. Prediction of nitrogen and phosphorus contents in citrus leaves based on hyperspectral imaging. Int. J. Agric. Biol. Eng. 2015, 8, 80-88.

49. Xu, X.G.; Zhao, C.J.; Wang, J.H.; Zhang, J.C.; Song, X.Y. Using optimal combination method and in situ hyperspectral measurements to estimate leaf nitrogen concentration in barley. Precis. Agric. 2014, 15, 227-240. [CrossRef]

50. Cilia, C.; Panigada, C.; Rossini, M.; Meroni, M.; Busetto, L.; Amaducci, S.; Boschetti, M.; Picchi, V.; Colombo, R. Nitrogen Status Assessment for Variable Rate Fertilization in Maize through Hyperspectral Imagery. Remote Sens. 2014, 6, 6549-6565. [CrossRef]

51. Quemada, M.; Gabriel, J.L.; Zarco-Tejada, P. Airborne Hyperspectral Images and Ground-Level Optical Sensors As Assessment Tools for Maize Nitrogen Fertilization. Remote Sens. 2014, 6, 2940-2962. [CrossRef] 
52. Liu, S.; Li, L.; Gao, W.; Zhang, Y.; Liu, Y.; Wang, S.; Lu, J. Diagnosis of nitrogen status in winter oilseed rape (Brassica napus L.) using in-situ hyperspectral data and unmanned aerial vehicle (UAV) multispectral images. Comput. Electron. Agric. 2018, 151, 185-195. [CrossRef]

53. Feng, D.; Xu, W.; He, Z.; Zhao, W.; Yang, M. Advances in plant nutrition diagnosis based on remote sensing and computer application. Neural Comput. Appl. 2019, 2019. [CrossRef]

54. Yang, G.; Liu, J.; Zhao, C.; Li, Z.; Huang, Y.; Yu, H.; Xu, B.; Yang, X.; Zhu, D.; Zhang, X. Unmanned Aerial Vehicle Remote Sensing for Field-Based Crop Phenotyping: Current Status and Perspectives. Front. Plant Sci. 2017, 8, 1111. [CrossRef]

55. Baresel, J.P.; Rischbeck, P.; Hu, Y.; Kipp, S.; Barmeier, G.; Mistele, B. Use of a digital camera as alternative method for non-destructive detection of the leaf chlorophyll content and the nitrogen nutrition status in wheat. Comput. Electron. Agric. 2017, 140, 25-33. [CrossRef]

56. Li, Z.; Li, Z.; Fairbairn, D.; Li, N.; Xu, B.; Feng, H. Multi-LUTs method for canopy nitrogen density estimation in winter wheat by field and UAV hyperspectral. Comput. Electron. Agric. 2019, 162, 174-182. [CrossRef]

57. Ulissi, V.; Antonucci, F.; Benincasa, P.; Farneselli, M.; Tosti, G.; Guiducci, M.; Tei, F.; Costa, C.; Pallottino, F.; Pari, L.; et al. Nitrogen concentration estimation in tomato leaves by VIS-NIR non-destructive spectroscopy. Sensors 2011, 11, 6411-6424. [CrossRef] [PubMed]

58. Roumet, P. Assessing leaf nitrogen content and leaf mass per unit area of wheat in the field throughout plant cycle with a portable spectrometer. F. Crop. Res. 2013, 140, 44-50.

59. Zhang, J. Potential of continuum removed reflectance spectral features estimating nitrogen nutrition in rice canopy level. In Proceedings of the 2010 2nd Workshop on. Hyperspectral Image and Signal Processing: Evolution in Remote Sensing (WHISPERS), Reykjavik, Iceland, 14-16 June 2010.

60. Yu, K.; Li, F.; Gnyp, M.L.; Miao, Y.; Bareth, G.; Chen, X. Remotely detecting canopy nitrogen concentration and uptake of paddy rice in the Northeast China Plain. ISPRS J. Photogramm. Remote Sens. 2013, 78, 102-115.

61. Gnyp, M.L.; Panitzki, M.; Reusch, S. Comparison between tractor-based and UAV-based spectrometer measurements in winter wheat. In Proceedings of the 13th International Conference on Precision Agriculture, St. Louis, MI, USA, 31 July-3 August 2016.

62. Ferwerda, J.G.; Skidmore, A.K.; Mutanga, O. Nitrogen detection with hyperspectral normalized ratio indices across multiple plant species. Int. J. Remote Sens. 1996, 26, 4083-4095. [CrossRef]

63. Chen, P.; Haboudane, D.; Tremblay, N.; Wang, J.; Vigneault, P.; Li, B. New spectral indicator assessing the efficiency of crop nitrogen treatment in corn and wheat. Remote Sens. Environ. 2010, 114, 1987-1997. [CrossRef]

64. Delegido, J.; Alonso, L.; Abad, G.G.; Jose, M. Moreno Estimating chlorophyll content of crops from hyperspectral data using a normalized area over reflectance curve (NAOC). J. Appl. Earth Obs. Geoinf. 2010, 2010, 165-174. [CrossRef]

65. Tian, Y.C.; Yao, X.; Yang, J.; Cao, W.X.; Hannaway, D.; Zhu, Y. Assessing newly developed and published vegetation indices for estimating rice leaf nitrogen concentration with ground- and space-based hyperspectral reflectance. F. Crop. Res. 2011, 120, 299-310. [CrossRef]

66. Ren, H.; Zhou, G.; Zhang, X. Estimation of green aboveground biomass of desert steppe in Inner Mongolia based on red-edge reflectance curve area method. Biosyst. Eng. 2011, 109, 385-395. [CrossRef]

67. Rouse, J.W.; Haas, R.H.; Deering, D.W.; Scheel, J.A.; Harlan, J. Monitoring the Vernal Advancement and Retrogradation (Green wave Effect) of Natural Vegetation; National Aeronautics and Space Administration (NASA)/Goddard Sp. Flight Cent. Type III Final Report; NASA/GSFC: Greenbelt, MD, USA, 1974.

68. Bao, Y.; Xu, K.; Min, J.; Xu, J. Estimating wheat shoot nitrogen content at vegetative stage from in situ hyperspectral measurements. Crop Sci. 2013, 53, 2063-2071. [CrossRef]

69. Gitelson, A.A.; Viña, A.; Ciganda, V.S.; Rundquist, D.C.; Arkebauer, T.J. Remote estimation of canopy chlorophyll in crops. Geophys. Res. Lett. 2005, 32. [CrossRef]

70. Feng, W.; Guo, B.B.; Wang, Z.J.; He, L.; Song, X.; Wang, Y.H.; Guo, T.C. Measuring leaf nitrogen concentration in winter wheat using double-peak spectral reflection remote sensing data. Field Crop. Res. 2014, 159, 43-52. [CrossRef]

71. He, L.; Zhang, H.Y.; Zhang, Y.S.; Song, X.; Feng, W.; Kang, G.Z.; Wang, C.Y.; Guo, T.C. Estimating canopy leaf nitrogen concentration in winter wheat based on multi-angular hyperspectral remote sensing: The journal of the European Society for Agronomy. Eur. J. Agron. 2016, 73, 170-185. [CrossRef] 
72. Guo, B.-B.; Qi, S.L.; Heng, Y.R.; Duan, J.Z.; Zhang, H.Y.; Wu, Y.P.; Feng, W.; Xie, Y.X.; Zhu, Y.J. Remotely assessing leaf $\mathrm{N}$ uptake in winter wheat based on canopy hyperspectral red-edge absorption. Eur. J. Agron. 2016, 82, 113-124. [CrossRef]

73. Blackburn, G.A. Quantifying chlorophylls and carotenoids at leaf and canopy scales: An evaluation of some hyperspectral approaches. Remote Sens. Environ. 1998, 66, 273-285. [CrossRef]

74. Sims, D.A.; Gamon, J.A. Relationships between leaf pigment content and spectral reflectance across a wide range of species, leaf structures and developmental stages. Remote Sens. Environ. 2002, 81, 337-354. [CrossRef]

75. Daughtry, C.S.T.; Walthall, C.L.; Kim, M.S.; De Colstoun, E.B.; McMurtrey, J.E. Estimating corn leaf chlorophyll concentration from leaf and canopy reflectance. Remote Sens. Environ. 2000, 74, 229-239. [CrossRef]

76. Haboudane, D.; Miller, J.R.; Tremblay, N.; Zarco-Tejada, P.J.; Dextraze, L. Integrated narrow-band vegetation indices for prediction of crop chlorophyll content for application to precision agriculture. Remote Sens. Environ. 2002, 81, 416-426. [CrossRef]

77. Jia, B.; He, H.; Ma, F.; Diao, M.; Jiang, G.; Zheng, Z.; Cui, J.; Fan, H. Use of a digital camera to monitor the growth and nitrogen status of cotton. Sci. World J. 2014, 2014, 19-22. [CrossRef]

78. Wang, J.; Shen, C.; Liu, N.; Jin, X.; Fan, X.; Dong, C.; Xu, Y. Non-Destructive Evaluation of the Leaf Nitrogen Concentration by In-Field Visible/Near-Infrared Spectroscopy in Pear Orchards. Sensors 2017, 17, 538. [CrossRef]

79. Xu, X.G.; Zhao, C.J.; Wang, J.H.; Li, C.J.; Yang, X.D. Associating new spectral features from visible and near infrared regions with optimal combination principle to monitor leaf nitrogen concentration in barley. J. INFRARED Millim. WAVES 2013, 32, 351. [CrossRef]

80. Maire, L.E.; Francois, C.; Dufrene, E. Towards universal broad leaf chlorophyll indices using PROSPECT simulated database and hyperspectral reflectance measurements. Remote Sens. Environ. 2004, 89, 1-28. [CrossRef]

81. Huete, A.R. A soil-adjusted vegetation index (SAVI). Remote Sens. Environ. 1988, 25, 295-309. [CrossRef]

82. Qi, J.; Chehbouni, A.; Huete, A.R.; Kerr, Y.H.; Sorooshian, S.S. A modified soil adjusted vegetation index. Remote Sens. Envrion. 2015, 48, 119-126. [CrossRef]

83. Rondeaux, G.; Steven, M.; Baret, F. Optimization of Soil-Adjusted Vegetation Indices. Remote Sens. Environ. 1996, 55, 95-107. [CrossRef]

84. Clevers, J.G.P.W.; Kooistra, L. Using hyperspectral remote sensing data for retrieving canopy chlorophyll and nitrogen content. IEEE J. Sel. Top. Appl. Earth Obs. Remote Sens. 2012, 5, 574-583. [CrossRef]

85. Wang, W.; Yao, X.; Yao, X.F.; Tian, Y.C.; Liu, X.J.; Ni, J.; Cao, W.X.; Zhu, Y. Estimating leaf nitrogen concentration with three-band vegetation indices in rice and wheat. Field Crop. Res. 2012, 129, 90-98. [CrossRef]

86. Wang, Y.; Liao, Q.; Yang, G.; Feng, H.; Yang, X.; Yue, J. Comparing broad-band and red edge-based spectral vegetation indices to estimate nitrogen concentration of crops using casi data. Int. Arch. Photogramm. Remote Sens. Spat. Inf. Sci. ISPRS Arch. 2016, 41, 137-143. [CrossRef]

87. Nevalainen, O.; Hakala, T.; Suomalainen, J.; Mäkipää, R.; Peltoniemi, M.; Krooks, A.; Kaasalainen, S. Fast and nondestructive method for leaf level chlorophyll estimation using hyperspectral LiDAR. Agric. For. Meteorol. 2014, 198, 250-258. [CrossRef]

88. Nevalainen, O.; Hakala, T.; Suomalainen, J.; Kaasalainen, S. Nitrogen concentration estimation with hyperspectral LiDAR. Remote Sens. Spat. Inf. Sci. 2013, II-5-W2, 205-210. [CrossRef]

89. Zhu, H.; Liu, H.; Xu, Y.; Yang, G. UAV-based hyperspectral analysis and spectral indices constructing for quantitatively monitoring leaf nitrogen content of winter wheat. Appl. Opt. 2018, 27, 7722-7732. [CrossRef] [PubMed]

90. Wen, P.-F.; He, J.; Ning, F.; Wang, R.; Zhang, Y.-H.; Li, J. Estimating leaf nitrogen concentration considering unsynchronized maize growth stages with canopy hyperspectral technique. Ecol. Indic. 2019, 107, 105590. [CrossRef]

91. Zhao, C.; Wang, Z.; Wang, J.; Huang, W. Relationships of leaf nitrogen concentration and canopy nitrogen density with spectral features parameters and narrow-band spectral indices calculated from field winter wheat (Triticum aestivum L.) spectra. Int. J. Remote Sens. 2012, 33, 3472-3491. [CrossRef]

92. Curran, P.J. Remote sensing of foliar chemistry. Remote Sens. Environ. 1990, 30, 271-278. [CrossRef] 
93. Li, F.; Miao, Y.; Feng, G.; Yuan, F.; Yue, S.; Gao, X.; Liu, Y.; Liu, B.; Ustin, S.L.; Chen, X. Improving estimation of summer maize nitrogen status with red edge-based spectral vegetation indices. Field Crop. Res. 2014, 157, 111-123. [CrossRef]

94. Schlemmera, M.; Gitelson, A.; Schepersa, J.; Fergusona, R.; Peng, Y.; Shanahana, J.; Rundquist, D. Remote estimation of nitrogen and chlorophyll contents in maize at leaf and canopy levels. Int. J. Appl. Earth Obs. Geoinf. 2013, 25, 47-54. [CrossRef]

95. Elshikha, D.M.; Barnes, E.M.; Clarke, T.R.; Hunsaker, D.J.; Haberland, J.A.; Pinter, J.P., Jr.; Waller, P.M.; Thompson, T.L. Remote Sensing of Cotton Nitrogen Status Using the Canopy Chlorophyll Content Index (CCCI). Trans. Asabe 2008, 51, 73-82.

96. Zhao, B.; Duan, A.; Ata-Ul-Karim, S.T.; Liu, Z.; Chen, Z.; Gong, Z.; Zhang, J.; Xiao, J.; Liu, Z.; Qin, A. Exploring new spectral bands and vegetation indices for estimating nitrogen nutrition index of summer maize. Eur. J. Agron. 2018, 93, 113-125. [CrossRef]

97. Wang, H.; Mortensen, A.K.; Mao, P.; Boelt, B.; Gislum, R. Estimating the nitrogen nutrition index in grass seed crops using a UAV-mounted multispectral camera. Int. J. Remote Sens. 2019, 40, 2467-2482. [CrossRef]

98. Gao, B.C.; Goetz, A.F.H. Extraction of dry leaf spectral features from reflectance spectra of green vegetation. Remote Sens. Environ. 1994, 47, 369-374. [CrossRef]

99. Ramoelo, A.; Skidmore, A.K.; Schlerf, M.; Mathieu, R.; Heitkönig, I.M.A. Water-removed spectra increase the retrieval accuracy when estimating savanna grass nitrogen and phosphorus concentrations. ISPRS J. Photogramm. Remote Sens. 2011, 66, 408-417. [CrossRef]

100. Schlerf, M.; Atzberger, C.; Hill, J.; Buddenbaum, H.; Werner, W.; Schüler, G. Retrieval of chlorophyll and nitrogen in Norway spruce (Picea abies L. Karst.) using imaging spectroscopy. Int. J. Appl. Earth Obs. Geoinf. 2010, 12, 17-26. [CrossRef]

101. Ramoelo, A.; Skidmore, A.K.; Schlerf, M.; Heitkönig, I.M.A.; Mathieu, R.; Cho, M.A. Savanna grass nitrogen to phosphorous ratio estimation using field spectroscopy and the potential for estimation with imaging spectroscopy. Int. J. Appl. Earth Obs. Geoinf. 2013, 23, 334-343. [CrossRef]

102. Feng, M.C.; Zhao, J.J.; Yang, W.D.; Wang, C.; Zhang, M.J.; Xiao, L.J.; Ding, G.W. Evaluating winter wheat (Triticum aestivum L.) nitrogen status using canopy spectrum reflectance and multiple statistical analysis. Spectrosc. Lett. 2016, 49, 507-513. [CrossRef]

103. Pearson, R.L.; Miller, L.D. Remote Mapping of Standing Crop Biomass for Estimation of Productivity of the Shortgrass Prairie. Remote Sens. Environ. 1972. [CrossRef]

104. Li, F.; Gnyp, M.L.; Jia, L.; Miao, Y.; Yu, Z.; Koppe, W.; Bareth, G.; Chen, X.; Zhang, F. Estimating N status of winter wheat using a handheld spectrometer in the North China Plain. Field Crop. Res. 2008, 106, 77-85. [CrossRef]

105. Tahir, M.N.; Li, J.; Liu, B.; Zhao, G.; Fuqi, Y.; Chengfeng, C. Hyperspectral estimation model for nitrogen contents of summer corn leaves under rainfed conditions. Pak. J. Bot. 2013, 45, 1623-1630.

106. Shi, J.; Zou, X.; Zhao, J.; Wang, K.; Chen, Z. Nondestructive diagnostics of nitrogen deficiency by cucumber leaf chlorophyll distribution map based on near infrared hyperspectral imaging. Sci. Hortic. 2012, 138, 190-197.

107. Nguyen, H.T.; Lee, B.W. Assessment of rice leaf growth and nitrogen status by hyperspectral canopy reflectance and partial least square regression. Eur. J. Agron. 2006, 24, 349-356. [CrossRef]

108. Wen, D.; Tongyu, X.; Fenghua, Y.; Chunling, C. Measurement of nitrogen content in rice by inversion of hyperspectral reflectance data from an unmanned aerial vehicle. Ciênc. Rural 2018, 48, e20180008. [CrossRef]

109. Perry, E.M.; Roberts, D.A. Sensitivity of Narrow-Band and Broad-Band Indices for Assessing Nitrogen Availability and Water Stress in an Annual Crop. Agron. J. 2008, 4, 969-996. [CrossRef]

110. Xue, L.; Cao, W.; Luo, W.; Dai, T.; Zhu, Y. Monitoring Leaf Nitrogen Status in Rice with Canopy Spectral Reflectance. Agron. J. 2004, 96, 135-142. [CrossRef]

111. Yoon, S.C.; Shin, T.S.; Heitschmidt, G.W.; Lawrence, K.C. Hyperspectral imaging using a color camera and its application for pathogen detection. Proc. SPIE 2015, 9405, 940506.

112. Li, X.; Zhang, Y.; Bao, Y.; Luo, J.; Yang, G. Exploring the Best Hyperspectral Features for LAI Estimation Using Partial Least Squares Regression. Remote Sens. 2014, 6, 6221-6241. [CrossRef]

113. Nigon, T.J.; Mulla, D.J.; Rosen, C.J.; Cohen, Y.; Alchanatis, V.; Knight, J.; Rud, R. Hyperspectral aerial imagery for detecting nitrogen stress in two potato cultivars. Comput. Electron. Agric. 2015, 112, 36-46. [CrossRef] 
114. Thorp, K.R.; Wang, G.; Bronson, K.F.; Badaruddin, M.; Mon, J. Hyperspectral data mining to identify relevant canopy spectral features for estimating durum wheat growth, nitrogen status, and grain yield. Comput. Electron. Agric. 2017, 136, 1-12. [CrossRef]

115. Li, Z.; Jin, X.; Yang, G.; Drummond, J.; Yang, H.; Clark, B.; Li, Z.; Zhao, C. Remote sensing of leaf and canopy nitrogen status in winter wheat (Triticum aestivum L.) based on N-PROSAIL model. Remote Sens. 2018, 10, 1-18. [CrossRef]

116. Mutanga, O.; Adam, E.; Adjorloloa, C.; Abdel-Rahmanw, E.M. Evaluating the robustness of models developed from field spectral data in predicting African grass foliar nitrogen concentration using WorldView-2 image as an independent test dataset. Int. J. Appl. Earth Obs. Geoinf. 2015, 34, 178-187. [CrossRef]

117. Miphokasap, P.; Wannasiri, W. Estimations of Nitrogen Concentration in sugarcane using hyperspectral imagery. Sustainability 2018, 10, 1266. [CrossRef]

118. Giorgos, M.; Jungho, I.; Caesar, O. Support vector machines in remote sensing: A review. ISPRS J. Photogramm. Remote Sens. 2011, 3, 247-259.

119. Axelsson, C.; Skidmore, A.K.; Schlerf, M.; Fauzi, A.; Verhoef, W. Hyperspectral analysis of mangrove foliar chemistry using PLSR and support vector regression. Int. J. Remote Sens. 2013, 34, 1724-1743. [CrossRef]

120. Li, L.; Jákli, B.; Lu, P.; Ren, T.; Ming, J.; Liu, S.; Wang, S.; Lu, J. Assessing leaf nitrogen concentration of winter oilseed rape with canopy hyperspectral technique considering a non-uniform vertical nitrogen distribution. Ind. Crops Prod. 2018, 116, 1-14. [CrossRef]

121. Chen, J.; Li, F.; Wang, R.; Fan, Y.; Raza, M.A.; Liu, Q.; Wang, Z.; Cheng, Y.; Wu, X.; Yang, F.; et al. Estimation of nitrogen and carbon content from soybean leaf reflectance spectra using wavelet analysis under shade stress. Comput. Electron. Agric. 2019, 156, 482-489. [CrossRef]

122. Ji-Yong, S.; Xiao-Bo, Z.; Jie-Wen, Z.; Han-Ping, M.; Kai-Liang, W.; Zheng-Wei, C.; Xiao-Wei, H. Diagnostics of nitrogen deficiency in mini-cucumber plant by near infrared reflectance spectroscopy. Afr. J. Biotechnol. 2011, 10, 19687-19692.

123. Pasolli, L.; Melgani, F.; Blanzieri, E. Gaussian Process Regression for Estimating Chlorophyll Concentration in Subsurface Waters From Remote Sensing Data. IEEE Geosci. Remote Sens. Lett. 2010, 7, 464-468. [CrossRef]

124. Verrelst, J.; Alonso, L.; Caicedo, J.P.R.; Moreno, J.; Camps-Valls, G. Gaussian Process Retrieval of Chlorophyll Content From Imaging Spectroscopy Data. IEEE J. Sel. Top. Appl. Earth Obs. Remote Sens. 2013, 6, 867-874. [CrossRef]

125. Arenas-García, J.; Petersen, K.B.; Campsvalls, G.; Hansen, L.K. Kernel Multivariate Analysis Framework for Supervised Subspace Learning: A Tutorial on Linear and Kernel Multivariate Methods. IEEE Signal Process. Mag. 2013, 30, 16-29. [CrossRef]

126. De Fátima da Silva, F.; Pedro, H.C.L.; Liliane, M.R.; Mário, A.M.; Alvaro, M.G.Z.; Valdo, R.H.; Odemir, M.B. A Diagnostic Tool for Magnesium Nutrition in Maize Based on Image Analysis of Different Leaf Sections. Crop Sci. 2014, 54, 738. [CrossRef]

127. Kyveryga, P.M.; Blackmer, T.M.; Pearson, R. Normalization of uncalibrated late-season digital aerial imagery for evaluating corn nitrogen status. Precis. Agric. 2012, 13, 2-16. [CrossRef]

128. Li, Y.; Chen, D.; Walker, C.N.; Angus, J.F. Estimating the nitrogen status of crops using a digital camera. Field Crop. Res. 2010, 118, 221-227. [CrossRef]

129. Pagola, M.; Ortiz, R.; Irigoyen, I.; Bustince, H.; Barrenechea, E.; Aparicio-Tejo, P.; Lamsfus, C.; Lasa, B. New method to assess barley nitrogen nutrition status based on image colour analysis: Comparison with SPAD-502. Comput. Electron. Agric. 2009, 65, 213-218. [CrossRef]

130. Laliberte, A.S.; Rango, A.; Herrick, J.E.; Fredrickson, E.L.; Burkett, L. An object-based image analysis approach for determining fractional cover of senescent and green vegetation with digital plot photography. J. Arid Environ. 2007, 69, 1-14. [CrossRef]

131. Sakamoto, T.; Wardlow, B.D.; Arkebauer, T.J.; Verma, S.B.; Suyker, A.E.; Shibayama, M. Application of day and night digital photographs for estimating maize biophysical characteristics. Precis. Agric. 2012, 13, 285-301. [CrossRef]

132. Näsi, R.; Viljanen, N.; Kaivosoja, J.; Alhonoja, K.; Hakala, T.; Markelin, L.; Honkavaara, E. Estimating Biomass and Nitrogen Amount of Barley and Grass Using UAV and Aircraft Based Spectral and Photogrammetric 3D Features. Remote Sens. 2018, 10, 1082. [CrossRef]

133. Tewari, V.K.; Kumar, A.A.; Kumar, S.P.; Pandey, V.; Chandel, N.S. Estimation of plant nitrogen content using digital image processing. Agric. Eng. Int. CIGR J. 2013, 2, 73-86. 
134. Wang, Y.; Wang, D.; Zhang, G.; Wang, C. Digital camera-based image segmentation of rice canopy and diagnosis of nitrogen nutrition. Nongye Gongcheng Xuebao/Trans. Chin. Soc. Agric. Eng. 2012, 28, 131-136.

135. Yuan, Y.; Chen, L.; Li, M.; Wu, N.; Wan, L.; Wang, S. Diagnosis of nitrogen nutrition of rice based on image processing of visible light. In Proceedings of the 2016 IEEE International Conference on Functional-Structural Plant Growth Modeling, Simulation, Visualization and Applications (FSPMA), Qingdao, China, 7-11 November 2016; pp. 228-232.

136. Elsayed, S.; Barmeier, G.; Schmidhalter, U. Passive Reflectance Sensing and Digital Image Analysis Allows for Assessing the Biomass and Nitrogen Status of Wheat in Early and Late Tillering Stages. Front. Plant Sci. 2018, 9, 1478. [CrossRef]

137. Mao, H.; Gao, H.; Zhang, X.; Kumi, F. Nondestructive measurement of total nitrogen in lettuce by integrating spectroscopy and computer vision. Sci. Hortic. 2015, 184, 1-7. [CrossRef]

138. Wang, Y.; Wang, D.; Zhang, G.; Wang, J. Estimating nitrogen status of rice using the image segmentation of G-R thresholding method. Field Crop. Res. 2013, 149, 33-39. [CrossRef]

139. Sulistyo, S.B.; Woo, W.L.; Dlay, S.S. Regularized Neural Networks Fusion and Genetic Algorithm Based On-Field Nitrogen Status Estimation of Wheat Plants. IEEE Trans. Ind. Inform. 2017, 13, 103-114. [CrossRef]

140. Chen, Z.; Wang, X.; Wang, H. Preliminary research on total nitrogen content prediction of sandalwood using the error-in-variable models based on digital image processing. PLoS ONE 2018, 8, e0202649. [CrossRef] [PubMed]

141. Purcell, L.C.; Mozaffari, M.; Karcher, D.E.; Andy King, C.; Marsh, M.C.; Longer, D.E. Association of "Greenness" in corn with yield and leaf Nitrogen concentration. Agron. J. 2011, 103, 529-535.

142. Bai, J.S.; Cao, W.D.; Xiong, J.; Zeng, N.H.; Katshyoshi, S.; Rui, Y.K. Nitrogen Status Diagnosis and Yield Prediction of Spring Maize after Green Manure Incorporation by Using a Digital Camera. Spectrosc. Spectr. Anal. 2013, 33, 3334.

143. Tang, L.; Tian, L.F.; Steward, B.L. Classification of Broadleaf and Grass Weeds Using Gabor Wavelets and an Artificial Neural Network. Trans. ASAE 2003, 46, 1247-1254. [CrossRef]

144. Ahmad, I.S. Evaluation of color representation schemes for maize images. J. Agric. Eng. Res. 1992, 3, $185-195$.

145. Tavakoli, H.; Gebbers, R. Assessing Nitrogen and water status of winter wheat using a digital camera. Comput. Electron. Agric. 2019, 157, 558-567. [CrossRef]

146. Zúñiga, A.M.G. Sistema de visão artificial para identificação do estado nutricional de plantas. Univ. Sao Paulo, Math. Comput. Sci. Inst. Sao Carlos, Brazil. 2012. Available online: https://teses.usp.br/teses/disponiveis/55/ 55134/tde-20062012-101012/publico/AlvaroGomezZuniga.pdf (accessed on 29 June 2020).

147. Sunagar, V.B.; Kattimani, P.A.; Padasali, V.A.; Hiremath, N.V. Estimation of Nitrogen Content in Leaves using Image Processing. In Proceedings of the International Conference on Advances in Engineering \& Technology, Goa, India, 20 April 2014; pp. 25-28.

148. Sun, Y.; Gao, J.; Wang, K.; Shen, Z.; Chen, L. Utilization of machine vision to monitor the dynamic responses of rice leaf morphology and colour to nitrogen, phosphorus, and potassium deficiencies. J. Spectrosc. 2018, 2018. [CrossRef]

149. Xiong, X.; Zhang, J.; Guo, D.; Chang, L.; Huang, D. Non-Invasive Sensing of Nitrogen in Plant Using Digital Images and Machine Learning for Brassica Campestris ssp. Chinensis L. Sensors 2019, 19, 2448. [CrossRef]

150. Chen, P. A Comparison of Two Approaches for Estimating the Wheat Nitrogen Nutrition Index Using Remote Sensing. Remote Sens. 2015, 7, 4527-4548. [CrossRef]

151. Huang, S.; Miao, Y.; Zhao, G.; Yuan, F.; Ma, X.; Tan, C.; Yu, W.; Gnyp, M.L.; Lenz-Wiedemann, V.I.S.; Rascher, U.; et al. Satellite remote sensing-based in-season diagnosis of rice nitrogen status in Northeast China. Remote Sens. 2015, 7, 10646-10667. [CrossRef]

152. Xia, T.; Miao, Y.; Wu, D.; Hui, S.; Khosla, R.; Mi, G. Active Optical Sensing of Spring Maize for In-Season Diagnosis of Nitrogen Status Based on Nitrogen Nutrition Index. Remote Sens. 2016, 8, 605. [CrossRef]

153. Moghaddam, P.A.; Derafshi, M.H.; Shayesteh, M. A new method in assessing sugar beet leaf nitrogen status through color image processing and artificial neural network. J. Food Agric. Environ. 2010, 8, 485-489.

154. Kusnierek, K.; Korsaeth, A. Simultaneous identification of spring wheat nitrogen and water status using visible and near infrared spectra and Powered Partial Least Squares Regression. Comput. Electron. Agric. 2015, 117, 200-213. [CrossRef]

155. Zeng, W.; Chi, X.; Wu, J.; Huang, J. Sunflower seed yield estimation under the interaction of soil salinity and nitrogen application. Field Crop. Res. 2016, 198, 1-15. [CrossRef] 
156. Sulistyo, S.B.; Woo, W.L.; Dlay, S.S.; Gao, B. Building a Globally Optimized Computational Intelligent Image Processing Algorithm for On-Site Inference of Nitrogen in Plants. IEEE Intell. Syst. 2018, 33, 15-26. [CrossRef]

157. Yao, X.; Zhu, Y.; Tian, Y.C.; Feng, W.; Cao, W.X. Exploring hyperspectral bands and estimation indices for leaf nitrogen accumulation in wheat. Int. J. Appl. Earth Obs. Geoinf. 2010, 12, 89-100. [CrossRef]

158. Ata-Ul-Karim, S.T.; Cao, Q.; Zhu, Y.; Tang, L.; Rehmani, M.I.; Cao, W. Non-destructive Assessment of Plant Nitrogen Parameters Using Leaf Chlorophyll Measurements in Rice. Front. Plant Sci. 2016, 7, 1829. [CrossRef]

159. Mistele, B.; Schmidhalter, U. Estimating the nitrogen nutrition index using spectral canopy reflectance measurements. Eur. J. Agron. 2008, 29, 184-190. [CrossRef]

160. Paleari, L.; Movedi, E.; Vesely, F.M.; Thoelke, W.; Tartarini, S.; Foi, M.; Boschetti, M.; Nutini, F.; Confalonieri, R. Estimating Crop Nutritional Status Using Smart Apps to Support Nitrogen Fertilization. A Case Study on Paddy Rice. Sensors 2019, 19, 981. [CrossRef]

161. Vleugels, T.; Rijckaert, G.; Gislum, R. Seed Yield Response to N Fertilization and Potential of Proximal Sensing in Italian Ryegrass Seed Crops. Field Crop. Res. 2017, 211, 37-47. [CrossRef]

162. Zhao, B.; Ata-Ul-Karim, S.T.; Liu, Z.; Ning, D.; Duan, A. Development of a critical nitrogen dilution curve based on leaf dry matter for summer maize. Field Crop. Res. 2017, 208, 60-68. [CrossRef]

163. Zhao, B.; Yao, X.; Tian, Y.C.; Liu, X.J.; Ata-Ul-Karim, S.T.; Ni, J.; Cao, W.X.; Zhu, Y. New Critical Nitrogen Curve Based on Leaf Area Index for Winter Wheat. Agron. J. 2014, 106, 379. [CrossRef]

164. Ata-Ul-Karim, S.T.; Zhu, Y.; Cao, Q.; Rehmani, M.I.A.; Cao, W.; Tang, L. In-season assessment of grain protein and amylose content in rice using critical nitrogen dilution curve. Eur. J. Agron. 2017, 90, 139-151. [CrossRef]

165. Dordas, C.A. Chlorophyll meter readings, $\mathrm{N}$ leaf concentration and their relationship with $\mathrm{N}$ use efficiency in oregano. J. Plant Nutr. 2017, 40, 391-403. [CrossRef]

166. Sridevy, S.; Vijendran, A.S.; Jagadeeswaran, R.; Djanaguiraman, M. Nitrogen and potassium deficiency identification in maize by image mining, spectral and true colour response. Indian J. Plant Physiol. 2018, 23, 91-99. [CrossRef]

167. Lu, Y.L.; Bai, Y.L.; Ma, D.L.; Lei, W.; Yang, L.P. Nitrogen Vertical Distribution and Status Estimation Using Spectral Data in Maize. Commun. Soil Sci. Plant Anal. 2018, 49, 1-11.

168. Ferreira, M. Sintomas de deficiência de macro e micronutrientes de plantas de milho híbrido BRS 1010. Rev. Agro@mbiente 2012, 1,74-83. [CrossRef]

169. Cohen, Y.; Alchanatis, V.; Zusman, Y.; Dar, Z.; Bonfil, D.J.; Karnieli, A.; Zilberman, A.; Moulin, A.; Ostrovsky, V.; Levi, A.; et al. Leaf nitrogen estimation in potato based on spectral data and on simulated bands of the VEN $\mu$ S satellite. Precis. Agric. 2010, 11, 520-537. [CrossRef]

170. Zhou, Z.; Jabloun, M.; Plauborg, F.; Andersen, M.N. Using ground-based spectral reflectance sensors and photography to estimate shoot $\mathrm{N}$ concentration and dry matter of potato. Comput. Electron. Agric. 2018, 144, 154-163. [CrossRef]

171. Pacheco-Labrador, J.; González Cascón, R.; Martín, M.P.; Riaño, D. Understanding the optical responses of leaf nitrogen in Mediterranean Holm oak (Quercus ilex) using field spectroscopy. Int. J. Appl. Earth Obs. Geoinf. 2014, 26, 105-118. [CrossRef]

172. Kokaly, R.F.; Clark, R.N. Spectroscopic determination of leaf biochemistry using band-depth analysis of absorption features and stepwise multiple linear regression. Remote Sens. Environ. 1999, 67, 267-287. [CrossRef]

173. Shiratsuchi, L.S. Integration of Plant-Based Canopy Sensors for Site-Specific Nitrogen Management. Horticulture 2011, 36, 222.

174. Reese, C. Nitrogen and Water Stress Impacts Hard Red Spring Wheat (Triticum aestivum) Canopy Reflectance. J. Terr. Obs. 2010, 2, 7.

175. Li, L.; Wang, S.; Ren, T.; Wei, Q.; Ming, J.; Li, J.; Li, X.; Cong, R.; Lu, J. Ability of models with effective wavelengths to monitor nitrogen and phosphorus status of winter oilseed rape leaves using in situ canopy spectroscopy. Field Crop. Res. 2018, 215, 173-186. [CrossRef]

176. Zhang, L.; Maki, H.; Ma, D.; Sánchez-Gallego, J.A.; Mickelbart, M.V.; Wang, L.; Rehman, T.U.; Jin, J. Optimized angles of the swing hyperspectral imaging system for single corn plant. Comput. Electron. Agric. 2019, 156, 349-359. [CrossRef] 
177. Özyiğit, Y.; BiLgen, M. Use of spectral reflectance values for determining nitrogen, phosphorus, and potassium contents of rangeland plants. J. Agric. Sci. Technol. 2018, 15, 1537-1545.

178. Min, M.; Lee, W.S.; Kim, Y.H.; Bucklin, R.A. Nondestructive detection of nitro-gen in Chinese cabbage leaves using VIS-NIR spectroscopy. HortScience 2006, 41, 162-166. [CrossRef]

179. Mitchell, J.J.; Glenn, N.F.; Sankey, T.T.; Derryberry, D.W.R.; Germino, M.J. Remote sensing of sagebrush canopy nitrogen. Remote Sens. Environ. 2012, 124, 217-223. [CrossRef]

180. Giacomelli, G.A.; Ling, P.P.; Kole, J. Determining nutrient stress in lettuce plantswith machine vision technology. Horttechnology 1998, 8, 361-365. [CrossRef]

181. Walch-Liu, P.; Neumann, G.; Bangerth, F.; Engels, C. Rapid effects of nitrogenform on leaf morphogenesis in tobacco. J. Exp. Bot. 2000, 51, 227-237. [CrossRef]

182. Xu, G.; Zhang, F.; Shah, S.G.; Ye, Y.; Mao, H. Use of leaf color images to identify nitrogen and potassium deficient tomatoes. Pattern Recognit. Lett. 2011, 32, 1584-1590. [CrossRef]

183. Kim, Y.; Reid, J.F. Modeling and Calibration of a Multi-Spectral Imaging Sensor for In-Field Crop Nitrogen Assessment. Appl. Eng. Agric. 2006, 22, 935-941. [CrossRef]

184. Story, D.; Kacira, M.; Kubota, C.; Akoglu, A.; An, L. Lettuce calcium deficiency detection with machine vision computed plant features in controlled environments. Comput. Electron. Agric. 2010, 74, 238-243. [CrossRef]

185. Xu, Y.; Wang, X.; Sun, H.; Wang, H. Study of Monitoring Maize Leaf Nutrition Based on Image Processing and Spectral Analysis. In Proceedings of the Third Ifip International Conference on Computer \& Computing Technologies in Agriculture, Beijing, China, 14-17 October 2009.

186. Chen, Q.; Zhang, Y.; Zhao, J.; Zhe, H. Nondestructive measurement of total volatile basic nitrogen (TVB-N) content in salted pork in jelly using a hyperspectral imaging technique combined with efficient hypercube processing algorithms. Anal. Methods 2013, 5, 6382-6388. [CrossRef]

187. Romualdo, L.M.; Luz, P.H.D.C.; Baesso, M.M.; de Fatima da Silva Devechio, F.; Bet, J.A. Spectral indexes for identification of nitrogen deficiency in maize. Rev. Cienc. Agron. 2018, 49, 183-191. [CrossRef]

188. Mulla, D.J. Twenty five years of remote sensing in precision agriculture: Key advances and remaining knowledge gaps. Biosyst. Eng. 2013, 114, 358-371. [CrossRef]

189. Garnett, T.; Conn, V.; Kaiser, B.N. Root based approaches to improving nitrogen use efficiency in plants. Plant Cell Environ. 2010, 32, 1272-1283. [CrossRef]

190. Gnyp, M.L.; Miao, Y.; Fei, Y.; Ustin, S.L.; Kang, Y.; Yao, Y.; Huang, S.; Bareth, G. Hyperspectral canopy sensing of paddy rice aboveground biomass at different growth stages. Field Crop. Res. 2014, 155, 42-55. [CrossRef]

191. Khanal, S.; Fulton, J.; Douridas, N.; Klopfenstein, A.; Shearer, S. Integrating aerial images for in-season nitrogen management in a corn field. Comput. Electron. Agric. 2018, 148, 121-131. [CrossRef]

192. Wang, Y.; Shi, P.; Ji, R.; Min, J.; Shi, W.; Wang, D. Development of a model using the nitrogen nutrition index to estimate in-season rice nitrogen requirement. Field Crop. Res. 2020, 245, 107664. [CrossRef]

193. Liu, X.F.; Lyu, Q.; He, S.L.; Yi, S.L.; Hu, D.Y.; Wang, Z.T.; Xie, R.J.; Zheng, Y.Q.; Deng, L. Estimation of carbon and nitrogen contents in citrus canopy by low-altitude remote sensing. Int. J. Agric. Biol. Eng. 2016, 9, 149-157.

194. Balafoutis, A.; Beck, B.; Fountas, S.; Vangeyte, J.; Van der Wal, T.; Soto, I.; Gómez-Barbero, M.; Barnes, A.; Eory, V. Precision Agriculture Technologies Positively Contributing to GHG Emissions Mitigation, Farm Productivity and Economics. Sustainability 2017, 9, 1339. [CrossRef]

195. Scharf, P.C.; Shannon, D.K.; Palm, H.L.; Sudduth, K.A.; Drummond, S.T.; Kitchen, N.R.; Mueller, L.J.; Hubbard, V.C.; Oliveira, L.F. Sensor-Based Nitrogen Applications Out-Performed Producer-Chosen Rates for Corn in On-Farm Demonstrations. Agron. J. 2011, 103, 1683. [CrossRef]

196. Yao, X.F.; Yao, X.; Tian, Y.C.; Ni, J.; Liu, X.J.; Cao, W.X.; Zhu, Y. A new method to determine central wavelength and optimal bandwidth for predicting plant nitrogen uptake in winter wheat. J. Integr. Agric. 2013, 12, 788-802. [CrossRef]

197. Gnyp, M.L.; Panitzki, M.; Reusch, S. Proximal nitrogen sensing by off-nadir and nadir measurements in winter wheat canopy. In Proceedings of the European Conference on Precision Agriculture, Volcani Center, Israel, 12-16 July 2015. [CrossRef]

(C) 2020 by the authors. Licensee MDPI, Basel, Switzerland. This article is an open access article distributed under the terms and conditions of the Creative Commons Attribution (CC BY) license (http://creativecommons.org/licenses/by/4.0/). 